\title{
BiST XKMYA İşletmelerinin Finansal Performanslarının Çok Kriterli Karar Verme Yöntemleri İle Ölçümü ve Yöntemlerin Karşılaştırılması*
}

\author{
The Evaluation of Financial Performances of BIST XKMYA Companies by \\ Multi-Criteria Decision Making Methods and Comparison of Methods
}

\author{
Serhat KARAOĞLAN ${ }^{1}$, Serap ŞAHIN²
}

\begin{abstract}
ÖZET
Bir işletmenin finansal performansının doğru analiz edilmesi gelecekte verilecek kararları belirlemek adına önem taşımaktadır. Çok sayıda faktör göz önüne alındığından dolayı Çok Kriterli Karar Verme (ÇKKV) yöntemleri finansal performans analizi için uygun birer araç olarak görülmektedir.
\end{abstract}

Bu çalışmada, BiST Kimya, Petrol, Plastik Endeksi'nde (XKMYA) yer alan işletmelerin finansal performansları analiz edilmiş olup, endekste yer alan 24 işletme sıralanmıştır. Belirlenen kriterler Analitik Hiyerarşi Süreci (AHP) yöntemi ile değerlendirilerek kriter ağırlıkları elde edilmiştir. Ardından, işletmelerin performansları, 2015 yılı bilançolarından elde edilen verilere göre, VIKOR, TOPSIS, GRA ve MOORA yöntemleri ile incelenmiş olup sıralanmıştır. Çalışmanın sonucunda 4 farklı ÇKKV yönteminin sonuçları karşılaştırılmıştır.

Anahtar Kelimeler: Çok Kriterli Karar Verme, Finansal Performans, Analitik Hiyerarşi Süreci, VIKOR, TOPSIS, Gri İlişkisel Analiz, MOORA.

\section{GiRiş}

Bir işte gösterilen başarı derecesi olarak özetlenebilecek olan performans kavramı, hizmet etkinliği, üretim verimliliği gibi, o işle amaçlanan hedefin ne ölçüde karşılandığının nicel ve nitel ifadesidir (Özer, 2009). Bir işletmeyi oluşturan bütün unsurlar, işletmenin toplam performansını etkilemektedirler.

Finansal performans kavramı ise, finansal ekonomideki gelişmeleri tam olarak yansıtamayan "kârı maksimum kılmak" düşüncesinin çok ötesine geçmiş

\begin{abstract}
Accuracy of financial performance analysis of a company has great importance in the purpose of future decisions. Multiple factors are taken into consideration while analysing financial performance of companies. For this reason, MultiCriteria Decision Making (MCDM) methods are appropriate for financial performance analysis.

In this study, performances of BIST Chemical Petroleum Plastic Index (XKMYA) which includes 24 companies were evaluated and put in order. Determinated criteria were evaluated by Analytic Hierarchy Process (AHP) method for obtaining criteria weights. Then, performances of companies were evaluated by VIKOR, TOPSIS, GRA and MOORA methods by means of year 2015 annual financial statements. As a result of this study, 4 different MCDM methods were compared.
\end{abstract}

Keywords: Multi-Criteria Decision Making, Financial Performance, Analytic Hierarchy Process, VIKOR, TOPSIS, Grey Relational Analysis, MOORA.

bulunmaktadır (Ertuğrul, 2009). Bir işletmenin, kaynaklarını ne derece etkin kullandığı ve finansal pozisyonu finansal performans olarak tanımlanabilir. Finansal performansı ölçmek için, verilerin toplanması, analiz edilmesi, doğru hedeflerin belirlenmesi, uygun ölçü setinin belirlenmesi gibi zor ve karmaşık, süreç ve mekanizmalar gereklidir (Aksoy, 2011).

İşletmeler açısından finansal performans, toplam çıktıdan öte, kaynakların ne derece etkin kullanıldığının ölçümüdür. Finansal performansın ölçümü ile elde edilen göstergeler, işletme ile ilgili karar verici

\footnotetext{
“Bu çalışma, Serhat Karaoğlan'ın Kırıkkale Üniversitesi, Sosyal Bilimler Enstitüsü, İşletme Anabilim Dalı'nda hazırlanan “BiST Kimya Petrol Plastik Endeksi'ndeki (XKMYA) İşletmelerin Finansal Performanslarının Çok Kriterli Karar Verme Yöntemleri İle Ölçümü" başlıklı yüksek lisans tezinden türetilmiştir

'Araştırma Görevlisi, Kırıkkale Üniversitesi, serhat@karaoglan.net

${ }^{2}$ Yrd. Doç. Dr., Kırıkkale Üniversitesi, serapsahin@kku.edu.tr
} 
kişi ve kurumlar için önemlidir. Bu göstergeler, yatırım, kredi, şirket birleşmesi gibi kararları yönlendirme ve etkileme işlevi görürler. Finansal performansın etkin bir biçimde ölçülmesi de bu sayılan sebeplerden dolayı önem teşkil etmektedir.

Ticaretin ve ekonominin geliştiği geçtiğimiz yüzyıl ve küreselleşmenin yüksek ölçüde hızlandığı son yıllarda, küresel pazarda faaliyet gösteren işletmelerin performanslarını ölçebilmek için grafik analizi, regresyon analizi, yüzde değişim analizi, oran analizi, performans karnesi, kumanda paneli gibi çok sayıda yöntem geliştirilmiştir. Bu çalışmada ise, ÇKKV yöntemleri ile finansal performans değerlendirmesi yapılmaktadır.

ÇKKV yöntemleri, belirli sayıda alternatif arasından en iyisini seçmek veya alternatifleri sıralamak amacıyla geliştirilmiş olsa da finansal performans analizinde, işletmeleri karşılaştırmak veya sıralamak amacıyla kullanılabilmektedir. Bu çalışmada finansal performans analizi yapmak amacıyla kullanılan ÇKKV yöntemleri, BIST (Borsa İstanbul) Kimya, Petrol, Plastik Endeksi'nde yer alan işletmeler üzerinde uygulanmıştır. Bu çalışma, sektörde yer alan işletmelerin finansal performansları hakkında fikir oluşturmanın yanı sıra, diğer endüstri kollarında da yöntemlerin uygulanması konusunda motivasyon sağlayacaktır.

Bugüne kadar ÇKKV yöntemleri ile yapılan finansal performans analizi çalışmaları, genellikle bir veya iki yöntem üzerinde durmuşlardır. Tablo 1 incelendiğinde, finansal performans analizi konusunda yapılan ulusal çalışmalarda kriter ağırlıklarının genellikle elde edilmediği görülmektedir. Kriterlerin farklı ağırlıklara sahip olabileceği ve karar verici için de ağırlıkların değişebileceği düşüncesinden hareketle, çalışmada kullanılan kriterlerin ağırlıklandırılmasının daha uygun olacağı kanaatine varılmıştır. Bununla birlikte, işletmelerin finansal performanslarını değerlendirmek için dört farklı ÇKKV yöntemi ile uygulama yapılmıştır. Uygulamanın sonucunda dört yöntemin sonuçlarını karşılaştırma imkânı olacaktır.

Kriterlerin ağırlıklandırılmasının AHP (Analitik Hiyerarşi Süreci) yöntemiyle, alternatiflerin değerlendirilmesinin ise VIKOR (Vise Kriterijumska Optimizacija I Kompromisno Resenje), TOPSIS (Technique for Order Preference by Similarity to an Ideal Solution), GRA (Gri Ilişkisel Analiz) ve MOORA (Multi-Objective Optimization on the basis of Ratio Analysis) yöntemleriyle yapıldığı bu çalışma üç bölümden oluşmaktadır.
Birinci bölümde ÇKKV yöntemleriyle yapılmış finansal performans analizi çalışmaları hem uluslararası hem de ulusal boyutta incelenmeye çalışılmıştır. Çalışmanın ikinci bölümünde ise uygulamada kullanılmış olan AHP, VIKOR, TOPSIS, GRA ve MOORA yöntemleri anlatılmıştır. Her bir yöntemden kısaca bahsedilmiş ve uygulama adımları sırasıyla gösterilmiştir. Son bölümde çalışmanın uygulamasına yer verilmiştir. Uygulama kısmında AHP yöntemi ile kriterler ağırlıklandırılmış ve kullanılan 4 ÇKKV yöntemi ile BIST Kimya, Petrol, Plastik Endeksi'nde yer alan işletmelerin finansal performansları analiz edilmiş ve işletmeler sıralanmıştır. Son olarak finansal performans analizi için kullanılan yöntemlerin karşılaştırması yapılmış ve ortaya çıkan bulgular değerlendirilmiştir.

\section{LITERATÜR ÖZETI}

İlk örneklerine 2000 yılının başlarında rastlanan ÇKKV yöntemleriyle finansal performans değerlendirme çalışmaları, son yıllarda daha fazla kullanıımaya başlanmıştır. Uluslararası çalışmaların bir bölümünde finansal oranların yanında, Ekonomik Katma Değer (EVA - Economic Value Added), Yatırımın Nakit Akım Kârlılı̆ı (CFROI - Cash Flow Return on Investment) ve Pazar Katma Değer (MVA - Market Value Added) gibi modern, değer temelli finansal performans göstergeleri de kullanılmaktadır.

Finansal performans analizi konusunda gerek ülkemizde gerekse yurtdışında farklı sektörlerde, farklı yöntem ve değişkenlerle yapılmış çalışmalar mevcuttur. Çalışmanın bu bölümünde, ÇKKV yöntemleri ile bu konuda daha önce yapılan çalışmalar iki bölüm halinde incelenmektedir. Yapılan literatür taraması sonucunda belirlenen, ÇKKV yöntemleri ile finansal performans analizi konulu uluslararası ve ulusal çalışmalar Tablo 1'de gösterilmektedir.

Tablo 1'deki Uluslararası çalışmalar incelendiğinde, TOPSIS ve VIKOR yöntemlerinin, işletmelerin finansal performansını değerlendirmede en sık kullanılan iki yöntem olduğu ve kriterlerin ağırlıklandırılmasında da Bulanık AHP yönteminin tercih edildiği görülmüştür.

Ayrıca Tablo 1'de yer alan Feng ve Wang (2000), Feng ve Wang (2001), Wang (2008), Wang (2009) ve Hsu (2015) tarafından yapılan çalışmalarda GRA yöntemi performans değerlendirme yöntemi olarak değil, temsili göstergeler (referans seriler) bulmak için kullanılmıştır. 
Ülkemizde yapılan çalışmalarda yoğun olarak TOPSIS yönteminin tercih edildiği, kriterlerin ağırlıklandırılmadığı gözlemlenmiştir. Bunun yanında VIKOR, ELECTRE (ELimination Et Choix Traduisant la REalité), GRA ve Veri Zarflama Analizi (VZA) de birden fazla çalışmada gözlemlenen yöntemler arasında yer almaktadır.

Ulusal çapta yapılan çalışmalarda BiST'te işlem gören işletmelerin sektörel bazda karşılaştırmaları yapılmıştır. Bazı çalışmalarda ise birden fazla yılın verileri kullanılarak, yıllara göre karşılaştırmalar yapılması tercih edilmiştir. Çalışmalarda, TCMB'nin yayımladığı finansal oranlar arasından seçili olanlar kullanılmış olup, bankacılık sektörü ile ilgili çalışmalarda sektöre özel oranlar da eklenmiştir. Uluslararası literatüre benzer şekilde 2000'li yılların başında yapılmaya başlanan ulusal düzeydeki ÇKKV ile finansal performans analizi çalışmaları, son yıllarda artmaya başlamıştır.

\section{3. ÇOK KRITERLI KARAR VERME YÖNTEMLERI}

Insanlar, karar verirken tek bir kriter üzerinden değerlendirme yapmamaktadırlar. Aynı şekilde işletmeler de değerlendirme yaparken, uzun dönemli faydaları için birden çok kriteri göz önünde bulundurmaktadırlar. Ancak çoğu zaman bir karar probleminde, bütün kriterleri aynı anda karşılayan mükemmel bir çözüm bulmak mümkün olmamaktadır. Bu nedenle karar problemlerinde alternatifler arasından, tüm kriterler değerlendirilerek ideal bir çözüm aranmaktadır (Ishizaka ve Nemery, 2013). ÇKKV kavramı da kısaca, birbiriyle çelişen birden çok amaç ile problem çözmek olarak tanımlanmaktadır (Zionts, 1979).

Tablo 1: Finansal Performans Analizinde ÇKKV Yöntemleri Kullanılan Çalışmalar

\begin{tabular}{|c|c|c|c|c|c|}
\hline \multicolumn{3}{|c|}{ Uluslararası } & \multicolumn{3}{|c|}{ Ulusal } \\
\hline YIl & Çalışmayı yapan & Yöntem & YIl & Çalışmayı yapan & Yöntem \\
\hline 2000 & Feng ve Wang & TOPSIS, GRA & 2003 & Yurdakul ve İç & TOPSIS \\
\hline 2001 & Feng ve Wang & TOPSIS, GRA & 2004 & Sekreter vd. & AHP \\
\hline 2008 & Wang & TOPSIS, GRA & 2010 & Dumanoğlu ve Ergül & TOPSIS \\
\hline 2009 & Wang & AHP, TOPSIS, GRA & 2010 & Dumanoğlu & TOPSIS \\
\hline 2009 & Seçme vd. & AHP, TOPSIS & 2010 & Demireli & TOPSIS \\
\hline 2009 & $\begin{array}{l}\text { Ertuğrul ve } \\
\text { Karakaşoğlu }\end{array}$ & AHP, TOPSIS & 2011 & Peker ve Baki & GRA \\
\hline 2010 & Wang ve Lee & GRA & 2011 & Akyüz vd. & TOPSIS \\
\hline 2012 & Baležentis vd. & $A H P, V I K O R, A R A S$ & 2011 & Bülbül ve Köse & TOPSIS, ELECTRE \\
\hline 2012 & Yalcin vd. & AHP, TOPSIS, VIKOR & 2011 & Çonkar vd. & TOPSIS \\
\hline 2014 & Çelen & AHP, TOPSIS & 2012 & $\begin{array}{c}\text { Bayrakdaroglu ve } \\
\text { Yalçın }\end{array}$ & $A H P, \mathrm{VIKOR}$ \\
\hline 2014 & Ghadikolaei vd. & $\begin{array}{c}\text { AHP, VIKOR, ARAS, } \\
\text { COPRAS }\end{array}$ & 2012 & Uygurtürk ve Korkmaz & TOPSIS \\
\hline 2014 & Esbouei vd. & $A N P$, VIKOR & 2012 & Perçin ve Karakaya & AHP, TOPSIS \\
\hline 2014 & Shaverdi vd. & $A H P$ & 2012 & Türkmen ve Çağıl & TOPSIS \\
\hline 2014 & Shen ve Tzeng & VIKOR, DRSA, DANP & 2012 & Soba vd. & TOPSIS, VZA \\
\hline \multirow[t]{8}{*}{2015} & $\mathrm{Hsu}$ & $\begin{array}{c}\text { VIKOR, GRA, Entropi, } \\
\text { VZA }\end{array}$ & 2012 & Yayar ve Baykara & TOPSIS \\
\hline & & & 2012 & Özden vd. & VIKOR \\
\hline & & & 2013 & Aytekin ve Sakarya & TOPSIS \\
\hline & & & 2014 & Saldanlı ve Sırma & TOPSIS \\
\hline & & & 2014 & Bakırcı vd. & TOPSIS, VZA \\
\hline & & & 2014 & Ergül & TOPSIS, ELECTRE \\
\hline & & & 2014 & Tayyar vd. & AHP, GRA \\
\hline & & & 2015 & İç vd. & $\begin{array}{c}\text { TOPSIS, VIKOR, GRA, } \\
\text { MOORA }\end{array}$ \\
\hline
\end{tabular}


Karar vermenin hemen hemen her alanında karşımıza çıkan ÇKKV problemlerini çözüme ulaştırmak için çok sayıda yöntem geliştirilmiştir. Yöntemlerin bir kısmı kriterleri ağırlıklandırırken bir kısmı da alternatifleri değerlendirme işlevi görmektedir. AHP, ANP gibi bazı yöntemler de hem kriter ağırlıklandırmasında hem de alternatif değerlendirmesinde kullanılabilmektedir.

\subsection{Analitik Hiyerarşi Süreci (AHP)}

AHP yöntemi, Saaty tarafından (1980) geliştirilmiş ve uygulama alanının genişliği, uygulama kolaylığı, hem sübjektif hem de objektif verileri değerlendirebilmesi sebebiyle en çok kullanılan ve bilinen ÇKKV yöntemlerden birisi haline gelmiştir (Vaidya ve Kumar, 2006; Dolan, 2008; Ho, 2008). Yöntem, yapısı gereği karmaşık ve zor problemleri çözmek için uygundur (Zahedi, 1986). Ayrıca bulanık mantık, doğrusal programlama gibi birçok teknikle uyum sağlaması da yöntemin tercih edilmesine neden olmaktadır. Bu sebeple de literatürde AHP'nin kullanıldığı çok sayıda hibrit ve bütünleşik uygulamalar yer almaktadır.

Yöntemin amacı, hiyerarşik yapıda yer alan bir aktivite içinde bulunan her bir kriterin önem derecelerini ve ağırlıklarını belirlemektir (Saaty, 1977). AHP, karar vermenin temel problemini oluşturan, farklı kriterlerin etkisinde olan bir dizi alternatif arasından en iyisini seçme sorunsalında, kapsamlı bir çerçeve sunmaktadır (Saaty, 1986). Diğer deyişle AHP yöntemi hem kriterleri ağırlıklandırmada hem de alternatifleri değerlendirmede kullanılabilmektedir. Bu yöntemde alternatiflerin değerlendirilmesi, ikili karşılaştırmalar temeline dayanmaktadır.

\subsubsection{AHP Yöntemi Uygulama Adımları}

AHP yöntemi ile bir karar verme problemini çözme işlemi aşağıda açıklanan dört adımdan oluşmaktadır (Zahedi, 1986).

Adım 1: Birbirleri ile ilişkili kriterler göz önünde bulundurularak problem, hiyerarşik bir yapıya dönüştürülür.
Adım 2: İkili karşılaştırmalar yoluyla karar elemanlarına ait veriler toplanır. Karar elemanlarına yani kriterlere veya alternatiflere ait veriler toplanırken Tablo 2'deki ikili karşılaştırma skalası kullanılarak sözlü olarak aldığımız yanıtlar sayısal verilere dönüştürülmektedir. Tam sayı değerlerin karşılığı olan tanımları tam karşılamayan, ara değerlere ait fikri olan karar vericinin yanıtları karşılığında rasyonel değerler kullanılmaktadır. Ayrıca $i$ faktörünün $j$ faktörüne göre önem derecesi, $j$ faktörünün $i$ faktörüne göre önem derecesinin tersi olarak alınacaktır (Saaty, 1977).

Adım 3: Karar elemanlarının nispi önem derecelerini belirlemek için özdeğer yöntemi uygulanır. AHP yönteminin bu basamağında, ikili karşılaştırmalar sonucu oluşan matristeki değerler ile hiyerarşik yapının her seviyesindeki kriterlerin, nispi ağırlıklarını bulmak için birtakım hesaplamalar yapılmaktadır. Bu hesaplamalarda izlenecek yol sırasıyla şu şekildedir. İlk olarak matristeki her bir değer, kendi sütun toplamına oranlanarak, sütun toplamları "1" olan normalize matris elde edilmektedir. Ardından bu normalize matrisin satır toplamları, matrisin boyutuna bölünerek "öncelik vektörü" adı verilen kriter ağırlıkları (w) bulunmaktadır.

Kriter ağırlıklarının elde edilmesinin ardından, her bir ikili karşılaştırma matrisi için tutarlılık indeksi hesaplanmaktadır. Bunun için de öncelikle;

$$
\lambda_{\max }=\frac{1}{n} \sum_{i=1}^{n}\left[\frac{\sum_{j=1}^{n} c_{i j} W_{j}}{w_{i}}\right]
$$

eşitliği ile $\lambda_{\max }$ değeri hesaplanmaktadır. $\lambda_{\max }$ değeri "Tutarlılık İndeksi" (TI) hesaplanmasında kullanılmaktadır. Tutarlılık indeksi ise,

$$
T I=\frac{\lambda_{\max }-n}{n-1}
$$

şeklinde ifade edilebilir. Eşitlik 2'deki, " $n$ " matris büyüklüğünü göstermektedir. Tutarlılık indeksinin hesaplanmasının ardından, "Tutarlılık Oranı"(TO),

Tablo 2: Ikili Karşılaştırma Skalası (Saaty, 1977)

\begin{tabular}{ccc}
\hline Değer & Tanım & Açıklama \\
\hline 1 & Eşit & İki faktör de eşit öneme sahip \\
3 & Biraz & 1. faktör 2. faktöre göre biraz daha önemli \\
5 & Kuvvetli & 1. faktör 2. faktörden daha önemli \\
7 & Çok kuvvetli & 1. faktör 2. faktörden çok önemli \\
9 & Kesin & 1. faktör 2. faktörden mutlak olarak üstün bir şekilde önemli \\
$2,4,6,8$ & Ara değerler & Uzlaşma gerektiğinde kullanılabilir \\
\hline
\end{tabular}

1. faktörün 2. faktörden daha önemsiz olması durumda ise $1 / 3,1 / 5,1 / 7$ ve $1 / 9$ değerleri kullanılmaktadır. 


$$
T O=\frac{T I}{R I}
$$

şeklinde hesaplanır. Tutarlılık oranının "0,1" değerinden küçük olması durumunda model tutarlıdır denilmektedir. Tutarlılık oranı ne kadar düşükse, modelin güvenilirliği o kadar yüksek olacaktır. Tutarlılık oranı hesaplanırken matris büyüklüğüne göre farklı “Rassal İndeks” (RI) değerleri kullanılır (Tablo 3).

Tablo 3: Rassal İndeks Tablosu (Alonso ve Lamata, 2006)

\begin{tabular}{ccccccc}
\hline $\mathbf{n}$ & $\mathbf{3}$ & $\mathbf{4}$ & $\mathbf{5}$ & $\mathbf{6}$ & $\mathbf{7}$ & $\mathbf{8}$ \\
\hline $\mathbf{R I}$ & 0.5247 & 0,8816 & 1,1086 & 1,2479 & 1,3417 & 1,4057 \\
\hline $\mathbf{9}$ & $\mathbf{1 0}$ & $\mathbf{1 1}$ & $\mathbf{1 2}$ & $\mathbf{1 3}$ & $\mathbf{1 4}$ & $\mathbf{1 5}$ \\
\hline 1,4499 & 1,4854 & 1,5140 & 1,5365 & 1,5551 & 1,5713 & 1,5838 \\
\hline
\end{tabular}

Adım 4: Alternatiflerin veya çıktıların derecelerine ulaşmak için karar elemanlarının nispi önem dereceleri toplanır.

\subsection{VIKOR}

Serafim Opricovic tarafından birbirleri ile ilişkisi olmayan kriterlerden oluşan karar problemlerini çözmek amacıyla geliştirilmiş bir yöntemdir. VIKOR yöntemi, ÇKKV problemine, en yüksek grup faydası ve en düşük bireysel pişmanlığı sağlayacak bir çözüm bulmayı amaçlamaktadır (Yıldız ve Deveci, 2013). Illk olarak 1998 yılında Opricovic tarafından gerçek dünya uygulamasında kullanılan yöntem, Opricovic ve Tzeng'in (2004) çalışması ile uluslararası tanınırlık kazanmıştır. Bu yöntem ile alternatifler değerlendirilerek uzlaşık bir çözüm bulmak amaçlanmaktadır.

\subsubsection{VIKOR Yöntemi Uygulama Adımları}

Alternatifleri değerlendirmek amacı ile uygulanmakta olan bir ÇKKV yöntemi olarak VIKOR, sırası ile aşağıdaki adımlardan oluşmaktadır. (Opricovic ve Tzeng, 2007; Görener, 2011).

Adım 1: Illk adımda, bir kriterin en iyi değerini gösteren $f_{j}^{*}$ ve en kötü değerini gösteren $f_{j}^{-}$değerleri hesaplanır ve burada $j=1,2,3, \ldots, n$ olarak tanımlıdır. Eğer $j$ kriteri bir fayda kriteri ise eşitlik;

$$
f_{j}^{*}=\max _{i} f_{i j} \quad \text { ve } \quad f_{j}^{-}=\min _{i} f_{i j}
$$

şeklinde ifade edilmektedir.

Adım 2: Sonraki aşamada, alternatifler için $S_{i}$ ve $R_{i}$ değerleri $(i=1,2,3, \ldots, m)$;

$$
\begin{aligned}
S_{i} & =\sum_{j=1}^{n}\left[w_{j}\left(f_{j}^{*}-f_{i j}\right) /\left(f_{j}^{*}-f_{j}^{-}\right)\right], \\
R_{i} & =\max _{j}\left[w_{j}\left(f_{j}^{*}-f_{i j}\right) /\left(f_{j}^{*}-f_{j}^{-}\right)\right],
\end{aligned}
$$

şeklinde hesaplanmaktadır. Yukarıdaki eşitliklerdeki $w_{j}$ değeri, kriter ağılıklarını yani kriterlerin önem derecelerini göstermektedir.

Eşitlik 5 ve $6^{\prime}$ daki $\left(f_{j}^{*}-f_{i j}\right) /\left(f_{j}^{*}-f_{j}^{-}\right)$normalize karar matrisini ifade ederken, $\left[w_{j}\left(f_{j}^{*}-f_{i j}\right) /\left(f_{j}^{*}-f_{j}^{-}\right)\right]$ eşitliği, ağırlıklandırılmış normalize karar matrisini göstermektedir.

Adım 3: Bu aşamada her bir alternatif için $Q_{i}$ değerleri,

$$
\begin{aligned}
& S^{*}=\min _{i} S_{i}, S^{-}=\max _{i} S_{i}, R^{*}= \\
& \min _{i} R_{i} \text { ve } R^{-}=\max _{i} R_{i} \text { ifade etmek üzere; } \\
& Q_{i}=v \frac{\left(S_{i}-S^{*}\right)}{\left(S^{-}-S^{*}\right)}+(1-v) \frac{\left(R_{j}-R^{*}\right)}{\left(R^{-}-R^{*}\right)}
\end{aligned}
$$

eşitliği ile hesaplanmaktadır. Eşitlik 7'de kullanılan $v$ parametresi maksimum grup faydasını göstermekteyken, $(1-v)$ değeri ise karşıt görüşlerin minimum pişmanlığını ifade etmektedir.

Adım 4: Bu adımda alternatifler, 2. adımda hesaplanan $S$ ve $R$ değerleri ile 3. adımda hesaplanan $Q$ değerlerine göre büyükten küçüğe sıralanmaktadır. Bunun sonucunda 3 adet sıralama sonucu elde edilmektedir.

Adım 5: Sıralama işlemi sonucunda, en küçük $Q$ değerine sahip alternatifin $\left(a^{\prime}\right)$, en iyi alternatif olarak tanımlanabilmesi için, aşağıda "koşul 1" olarak gösterilen kabul edilebilir avantaj ve "koşul 2" olarak gösterilen kabul edilebilir istikrar koşullarını taşıması gerekmektedir.

Koşul 1: Kabul edilebilir avantaj, $Q\left(a^{\prime \prime}\right)-Q\left(a^{\prime}\right) \geq D Q$ koşuluna bağlıdır. Bu eşitsizlikte, $\left(a^{\prime \prime}\right) 4$. adımda gerçekleştirilmiş olan sıralama işlemlerinden $Q$ değerine göre en iyi 2. alternatifi ifade etmektedir. $D Q=1 /(m-1)$ eşitliği ile hesaplanmakta olup $n$ alternatif sayısını göstermektedir.

Koşul 2: Kabul edilebilir istikrar ise, en küçük $Q$ değerine sahip alternatif olan $\left(a^{\prime}\right)$ alternatifi, $S$ ve/veya $R$ değerlerine göre de en iyi alternatif olmalıdır. Koşul 2'nin gerçekleşmesi, karar verme sürecinde uzlaşık çözüm kümesinin istikrarlı olduğunu göstermektedir.

Yukarıdaki 2 koşuldan birisinin sağlanmaması durumunda, uzlaşık çözüm kümesi aşağıda yazıldığı gibi oluşmaktadır: 
Eğer 2. koşul sağlanmıyorsa, $Q$ değerine göre en iyi iki alternatif olan $\left(a^{\prime}\right)$ ve $\left(a^{\prime \prime}\right)$ alternatifleri ortak çözüm olarak kabul edilir. 1. koşulun sağlanmaması durumunda ise $a^{\prime}, a^{\prime \prime}, \ldots, a^{(M)}$ alternatiflerinin hepsi ortak çözüm olarak kabul edilmektedir. $Q\left(a^{(M)}\right)-Q\left(a^{\prime}\right)<D Q$ ilişkisi ile, $a^{(M)}$ alternatifi için üst sınır olan en yüksek $M$ değeri belirlenmektedir.

\subsection{TOPSIS}

TOPSIS (Technique for Order Preference by Similarity to an Ideal Solution) yöntemi, Hwang ve Yoon tarafından, ÇKKV problemlerini çözmek amacıyla 1981 yılında geliştirilmiştir (Chen, 2000; Demireli, 2010). TOPSIS, alternatifleri ideal çözüme uzaklıklarına göre sıralayan pratik ve kullanışlı bir tekniktir (Shih, Shyur ve Lee, 2007). TOPSIS yöntemi bir alternatifin en iyi çözüme en yakın ve en kötü çözüme en uzak öklidyen mesafesi temeline dayanmaktadır (Zanakis vd., 1998). Pozitif İdeal Çözüm (PIS) olarak adlandırılan en iyi çözüme nispi yakınlık ve Negatif İdeal Çözüm (NIS) olarak adlandırılan en kötü çözüme nispi uzaklıkların bir kombinasyonuyla alternatifler sıralanmaktadır. TOPSIS yöntemiyle hesaplama yapabilmek için alternatiflerin bağımsız olması gerekmemektedir ancak tüm değerler sayısal ve ölçülebilir olmak durumundadır.

\subsubsection{TOPSIS Yöntemi Uygulama Adımları}

TOPSIS yöntemi, karar matrisinin oluşturulmasının ardından sırasıyla aşağıdaki beş adımdan oluşmaktadır (Jahanshahloo, Lotfi ve Izadikhah, 2006; Demireli, 2010; Behzadian vd., 2012).

1. Adım: Karar matrisinin normalize edilmesi aşamasıdır. Bu aşamada;

$$
R_{i j}=\frac{x_{i j}}{\sqrt{\sum_{i=1}^{m} x_{i j}^{2}}}
$$

eşitliği ile karar matrisindeki her bir kritere ait alternatif değerlerinin kareleri toplamının karekökü alınmaktadır. Ardından, her bir alternatif değeri, hesaplanmış olan bu değere oranlanmaktadır. Böylelikle matris normalleştirilmiş olur.

2. Adım: Ağırlıklandırıımış Normalize Karar Matrisini elde etmek için, varsa daha önceden belirlenmiş veya başka bir yöntem ile hesaplanmış olan kriter ağırlıkları matrisi ile 1. adımda elde edilen "Normalize Karar Matrisi" çarpılmaktadır.

$$
V_{i j}=R_{i j} \times w_{i j}
$$

3. Adım: Bu aşamada Pozitif ve Negatif İdeal Çözümler elde edilmektedir.

$$
\begin{aligned}
& A^{*}=\left\{\left(\max V_{i j} \mid j \in J\right\}\right. \\
& A^{-}=\left\{\left(\min V_{i j} \mid j \in J\right\}\right.
\end{aligned}
$$

Eşitlik 10 ve Eşitlik 11 ile sırasıyla her bir kriter için en iyi ve en kötü değerler bulunur.

4. Adım: Bu basamakta ayrım ölçüleri belirlenmektedir. Her bir alternatif için;

$$
\begin{aligned}
& S_{i}^{*}=\sum_{j=1}^{n}\left(v_{i j}-v_{j}^{+}\right)^{2} \\
& S_{i}^{-}=\sum_{j=1}^{n}\left(v_{i j}-v_{j}^{-}\right)^{2}
\end{aligned}
$$

eşitlikleri ile sırasıyla pozitif ideal noktaya ayrım ölçüsü $\left(S^{*}\right)$ ve negatif ideal noktaya ayrım ölçüsü $\left(S^{-}\right)$ hesaplanmaktadır.

5. Adım: Son aşamada ise, ideal çözüme nispi yakınlığı gösteren $C_{i}^{*}$ değeri;

$$
C_{i}^{*}=\frac{S_{i}^{-}}{S_{i}^{*}+S_{i}^{-}}, \quad 0<C_{i}^{*}<1
$$

eşitliği ile elde edilmektedir. Seçim problemlerinde en büyük değere sahip olan alternatif seçilmekteyken, sıralama probleminde ise elde edilen değere göre alternatifler büyükten küçüğe sıralanmaktadır.

\subsection{Gri İlişkisel Analiz (GRA)}

Gri Sistem Teorisi (GST), gri sistemler olarak adlandırılabilecek olan yapısal mesaj, operasyon mekanizması ve davranışlar gibi, bilgi eksikliği içeren; örneğin insan vücudu, tarım, ekonomi vb. gibi (Deng, 1989) belirsiz sistemlerin incelenmesi için 1960 'I yıllarda Julong Deng tarafından geliştirilmiştir (Liu, Forest ve Yang, 2012). GST, yetersiz veya sınırlı bilgi ile karakterize sistemlere uygulanabilmektedir.

Gri İlişkisel Analiz (GRA) ise Asya'da yaygın olarak kullanılan, iki dizi arasındaki benzerlikleri veya farklılıkları, ilişkileri temelinde ölçen, etki değerlendirme modelidir (Chan ve Tong, 2007). GRA, GST başlığı altında yer alan bir karar verme ve analiz yöntemidir (Özdemir ve Deste, 2009). GRA, belirsizliğin söz konusu olduğu durumlarda matematiksel analiz yöntemlerine nazaran daha kolay çözüm sunan, ÇKKV problemlerindeki belirsizlikleri çözümlemek (Peker ve Baki, 2011) ve çok sayıda kriterin ve değişkenin birbirleri arasındaki karmaşık ilişkilerini çözmek için kullanılan uygun bir yöntemdir (Bektaş ve Tuna, 
2013). Yöntemin odaklandığı sınırlı bilgi içeren küçük örneklem gruplarının dünyamızda yoğun olarak yer alması, bu yöntemin çok geniş uygulama alanı bulmasına sebep olmaktadır (Liu vd., 2012).

\subsubsection{GRA Yöntemi Uygulama Adımları}

GRA'nın ana prosedürü, alternatifleri birbirleri ile karşılaştırılabilecek diziler haline getirmektir. Alternatiflere ait ölçülen değerlerin farklı niteliklerde olması, bazı faktörlerin göz ardı edilmesine sebep olabilecektir (Kuo, Yang ve Huang, 2008). Veri setinin dağılımının çok geniş olması veya dizideki hedef yönlerinin farklı olması yani dizinin hem fayda hem de maliyet kriterlerinden oluşması durumunda da verilerin düzenlenmesi gerekmektedir (Fung, 2003). GRA yönteminin uygulaması sürecindeki adımlar şu şekildedir (Wu, 2002; Zhai, Khoo ve Zhong, 2009; Yıldırım, 2014)

1. Adım: Illk adımda veri seti hazırlanmakta ve karar matrisi $(X)$ oluşturulmaktadır. ÇKKV problemine ait, $m$ adet faktör serisi (alternatif) belirlenmektedir. Bu karar matrisinde $m$ adet seri $n$ adet kriter ile nitelendirilmektedir. Alternatiflerin her bir kriter için aldığı değerler $x_{i}(j)^{\prime}$ ler aracılığıyla gösterilmektedir.

2. Adım: Bu adımda referans serileri oluşturulmaktadır. Problemdeki faktörleri mukayese etmek için belirlenecek referans seri $j=1,2, \ldots, n$ iken $\left(x_{0}(j)\right)$ olacak şekilde ifade edilmektedir. $x_{0}(j)$, bir kritere ait normalleştirilmiş değerler içindeki maksimum değeri göstermektedir. Referans serisi, karar matrisine eklenerek karşılaştırma matrisine dönüştürülmektedir.

3. Adım: Bu adımda, karşılaştırma matrisi normalleştirilmektedir. GST'de "Gri iliş̧kisel Oluşum" adı verilen normalizasyon işlemi sonucunda (Chang, Tsai ve Chen, 2003; Tsai, Chang ve Chen, 2003) seriler 0-1 arası değerler almakta ve karşılaştııılabilir seviyeye gelmektedirler. Normalizasyon işlemi, kriterlerin yapısına göre üç farklı şekilde yapılmaktadır ve büyük olan iyidir, küçük olan iyidir veya ideal değer en iyisidir olarak adlandırılmaktadır (Zhai vd., 2009).

Fayda hesaplamalarında kullanılan, daha büyük değerin daha iyi olduğu yani değer büyüdükçe amaca katkısı olumlu yönde olduğu durumda normalizasyon işlemi;

$$
x_{i}^{*}=\frac{x_{i}(j)-\min _{j} x_{i}(j)}{\max _{j} x_{i}(j)-\min _{j} x_{i}(j)}
$$

eşitliği ile yapılmaktadır. Maliyet hesaplamalarında kullanılan, daha küçük değerin daha iyi olduğu yani değer küçüldükçe amaca katkısı olumlu yönde olduğu durumda normalizasyon işlemi ise;

$$
x_{i}^{*}=\frac{\max _{j} x_{i}(j)-x_{i}(j)}{\max _{j} x_{i}(j)-\min _{j} x_{i}(j)}
$$

şeklinde elde edilmektedir. Serinin, belirlenen veya bilinen ideal bir değere göre normalizasyon işlemi ise;

$$
x_{i}^{*}=\frac{\left|x_{i}(j)-x_{o b}(j)\right|}{\max _{j} x_{i}(j)-x_{o b}(j)}
$$

eşitliğinden hesaplanmaktadır. Eşitlikte yer alan $x_{o b}(j) j$. kriterin ideal değeri olup $\max _{j} x_{i}(j) \geq x_{o b}(j) \geq \min _{j} x_{i}(j)$ aralığında yer almaktadır. Adım 3'teki işlemlerin ardından karar matrisi, normalize matrise dönüşmüş olup $X^{*}$ ile gösterilmektedir.

4. Adım: Normalize değerler ve bu değerlere ait serilerin referans değerleri arasındaki farklar Eşitlik 18 'de gösterildiği gibi hesaplanır ve "Farklar Matrisi" oluşturulmaktadır.

$$
\Delta_{0 i}=\left|x_{0}^{*}(j)-x_{i}^{*}(j)\right|, i=1,2, \ldots, m ; j=1,2, \ldots, n
$$

5. Adım: Gri ilişkisel katsayının hesaplanması için;

$$
\gamma_{0 i}(j)=\frac{\Delta_{\min }+\zeta \Delta_{\max }}{\Delta_{0 i}(j)+\zeta \Delta_{\max }}
$$

eşitliği uygulanmaktadır ve bu eşitlikteki $\Delta_{\max }$ ve $\Delta_{\min }$ değerleri;

$$
\begin{aligned}
& \Delta_{\max }=\max _{i} \max _{j} \Delta_{01}(j) \\
& \Delta_{\min }=\min _{i} \min _{j} \Delta_{01}(j)
\end{aligned}
$$

şeklinde hesaplanmaktadır. Gri ilişkisel eşitliğinde yer alan " $\zeta$ " parametresi 0-1 aralığında değerler almaktadır ve "ayırıcı katsayı" veya "zıtlık kontrol katsayısı" olarak ifade edilmektedir (Yıldırım, 2014). Ayrıca bu katsayıyı "ayrıştıııcı katsayı" (Özdemir ve Deste, 2009) veya "ayırt edicilik indisi" olarak da isimlendirmek mümkündür. Literatürde sıklıkla $\zeta=0,5$ olarak kullanıldığı görülmektedir. Ayırt ediciliği 1'e yaklaştıkça arttıran, 0'a yaklaştıkça azaltan bu katsayı- 
nın değiştirilmesinin analiz sonuçlarına minör etkileri olabilmektedir (Omoniwa, 2014).

6. Adım: Son aşamada ise gri ilişkisel dereceler hesaplanmaktadır. Gri ilişsisel derece, karşılaştırılan $x_{i}^{*}$ serisi ile $x_{0}^{*}$ referans serisi arasındaki benzerliğin seviyesini göstermektedir. Gri ilişkisel derece 1'e yaklaştıkça, referans seri ile karşılaştırılan seri arasındaki ilişkinin kuvvetinin arttığı anlaşılmaktadır.

Gri ilişkisel dereceler,

$$
\begin{aligned}
& \Gamma_{0 i}=\sum_{j=1}^{n}\left[w_{i}(j) \cdot \gamma_{0 i}(j)\right], \sum_{j=1}^{n} w_{i}(j)=1, \\
& i=1,2, \ldots, m
\end{aligned}
$$

eşitliği ile hesaplanmaktadır. Eşitlik 22'deki $\Gamma_{0 i}, i$. serinin gri ilişkisel derecesini; $w_{i}(j)$ ise $j$. kriterin ağırlığını göstermekte olup, kriter ağılıkları uygulamayı yapan tarafından daha önceden belirlenmektedir. Son olarak gri ilişkisel derecelere göre alternatifler büyükten küçüğe doğru sıralanmaktadır. Sıralama sonucu üstte çıkan serinin, referans serisine benzerliğinin yüksek olduğu sonucuna varılmaktadır. Üstte çıkan seri, referans seriye en çok benzeyen seridir ve ideal çözüm yani en iyi alternatif olarak belirlenmektedir.

\subsection{MOORA}

Türkçeye "Oransal Analiz Temelli Çok Amaçlı Optimizasyon" olarak çevrilebilecek MOORA (Multi-Objective Optimization on the basis of Ratio Analysis), Brauers ve Zavadskas (2006) tarafından geliştirilmiş ve diğer sık kullanılan ÇKKV yöntemlerine göre nispeten daha yeni bir yöntemdir. Yeni bir yöntem olmasına karşılık ekonomi, yönetim ve mühendislik alanlarında çok sayıda uygulama yapılmıştır. Bir sıralama yöntemi olarak MOORA, işlem prosedürüne göre, iyi bilinen Basit Ağırlıklı Çarpım ve yaygın kullanılan TOPSIS yöntemleri arasında yer almaktadır (Stanujkic vd. 2012). Böylelikle, etkili ve kullanımı kolay bir yöntem olduğundan bahsetmek uygundur. Bir ÇKKV yöntemi olarak MOORA, alternatiflerin her biri için ölçülebilir değerler sunmakta, ulaşılan sonuçlarla da alternatiflerin karşılaştırılması için uygun bir zemin hazırlayarak, seçim yapmayı kolaylaştırmaktadır (Uygurtürk, 2015).

\subsubsection{MOORA Yöntemi Uygulama Adımları}

Yöntemin literatürde; Oran Metodu, Referans Noktası Yaklaşımı, Önem Katsayısı, Tam Çarpım Formu ve MULTIMOORA olmak üzere çeşitli varyasyonları bulunmaktadır. MOORA yönteminde tüm yaklaşımlar öncelikle oran metodu ile başlamaktadır ve ilk 3 adımda bu yöntem anlatılmıştır. Bu çalışmada ise kriter ağırlıkları kullanıldığı için önem katsayısı yaklaşımı uygulanmıştır ve 4. adım olarak ilgili yöntemin hesaplamalarına yer verilmiştir.

1. Adım: MOORA yöntemi, diğer birçok ÇKKV yönteminde olduğu gibi karar matrisi ile başlamaktadır. Bu karar matrisinde, farklı alternatiflerin, çeşitli amaçlara göre karşılıkları görülmektedir (Brauers ve Zavadskas, 2006; Özdağoğlu, 2014).

2. Adım: Karar matrisine normalizasyon işlemi yapılmaktadır. Bu aşamada;

$$
x_{i j}^{*}=\frac{x_{i j}}{\sqrt{\sum_{i=1}^{m} x_{i j}^{2}}}
$$

eşitliği ile her bir alternatif, ilgili kriterdeki tüm alternatiflerin kareleri toplamının kareköküne oranlanmaktadır. Böylelikle karar matrisi normalleştirilmektedir.

3. Adım: Bu aşamada alternatiflerin performans değerleri hesaplanmakta ve alternatifler sıralanmaktadır. Bunun için $j=1,2, \ldots, g$ fayda kriterleri, $j=g+1, g+2, \ldots, n$ maliyet kriterleri olmak üzere;

$$
y_{i}^{*}=\sum_{j=1}^{g} x_{i j}^{*}-\sum_{j=g+1}^{n} x_{i j}^{*}
$$

eşitliği ile bir alternatifin fayda kriterlerindeki değerleri toplamından, maliyet kriterlerindeki değerleri toplamı çıkarılarak $y_{i}^{*}$ değerleri elde edilmektedir. Eşitlikteki $y_{i}^{*}$ değeri, $j$ alternatifinin tüm kriterlere göre normalleştirilmiş değerlendirilmesi olarak adlandırılmaktadır (Ömürbek ve Özcan, 2016).

4. Adım: Gerçek hayatta çok nadir problemlerde kriterlerin ağırlıkları karar verici için eşit öneme sahip olmaktadır. Bu yüzden;

$$
y_{i}^{*}=\sum_{j=1}^{g} w_{j} x_{i j}^{*}-\sum_{j=g+1}^{n} w_{j} x_{i j}^{*}
$$

eşitliği kullanılarak daha önceden hesaplanmış $w_{j}$ kriter ağırlıkları da hesaplamalara dahil edilerek, alternatiflerin toplam performans değerleri hesaplanmaktadır (Stanujkic vd., 2012). 


\section{4. ÇKKV YÖNTEMLERIYLE PERFORMANS ÖLÇÜMÜ UYGULAMASI}

Çalışmada, ÇKKV yöntemleriyle performans değerlendirmesi yapmak amacıyla BiST Kimya, Petrol, Plastik Endeksi'ndeki işletmeler karşılaştırmaya tabi tutulmaktadır. Uygulamada, kriterleri ağırlıklandırmak için AHP, alternatifleri değerlendirmek için ise VIKOR, TOPSIS, GRA ve MOORA yöntemleri kullanılmaktadır. Bu dört yöntem, yapılan finansal performans analizinin ardından Spearman Sıra Korelasyon katsayısı ile karşılaştırılmaktadır ve sonuçların farklılık içerip içermediği incelenmektedir.

\subsection{Finansal Performansı Etkileyen Kriterlerin Belirlenmesi}

Bir ÇKKV probleminde kriterlerin doğru belirlenmesi, amaca ulaşmadaki etkinliği artırmaktadır. Kriterlerin belirlemesinde, karar problemin yapısına göre geçmiş deneyimler, konu hakkında yapılmış çalışmalar, uzman görüşleri veya karar vericinin ihtiyaçları yardımcı olmaktadır. Kimi zaman da bu sayılanlardan birkaçı veya hepsi bir bütün olarak kriter belirlenmesinde rol almaktadır.
Bu çalışmada, finansal oranlara göre performans değerlendirmesi yapmak için TCMB'nin yayımladığı oranlar göz önüne alınmıştır. Bununla birlikte literatürde, daha önce yapılmış benzer çalışmalar da incelenmiştir. Bu konu üzerine ülkemizde yapılan çalışmalar incelenirken, bankacılık sektörünün kendine özgü oranları olduğu için inceleme dışında bırakılmıştır.

Bütün bu ön çalışmaların sonucunda konunun uzmanları ile görüşmeler yapılarak, 4 ana kriter ile bu kriterlere bağlı olan 15 alt kriter belirlenmiştir ve bu kriterler çalışmada kullanılan kodları ile birlikte Şekil 1 'de hiyerarşik yapıda görülmektedir.

\subsection{Finansal Performansları Analiz Edilecek İşletmeler}

Çalışmanın uygulama bölümünde, BIST XKMYA işletmelerinin, finansal performansları analiz edilecektir. Kimya sektörünün çalışmaya konu edilmesinin sebebi, daha önceden yapılmış olan finansal performans analizi çalışmalarında bu sektöre rastlanmamış olmasıdır.

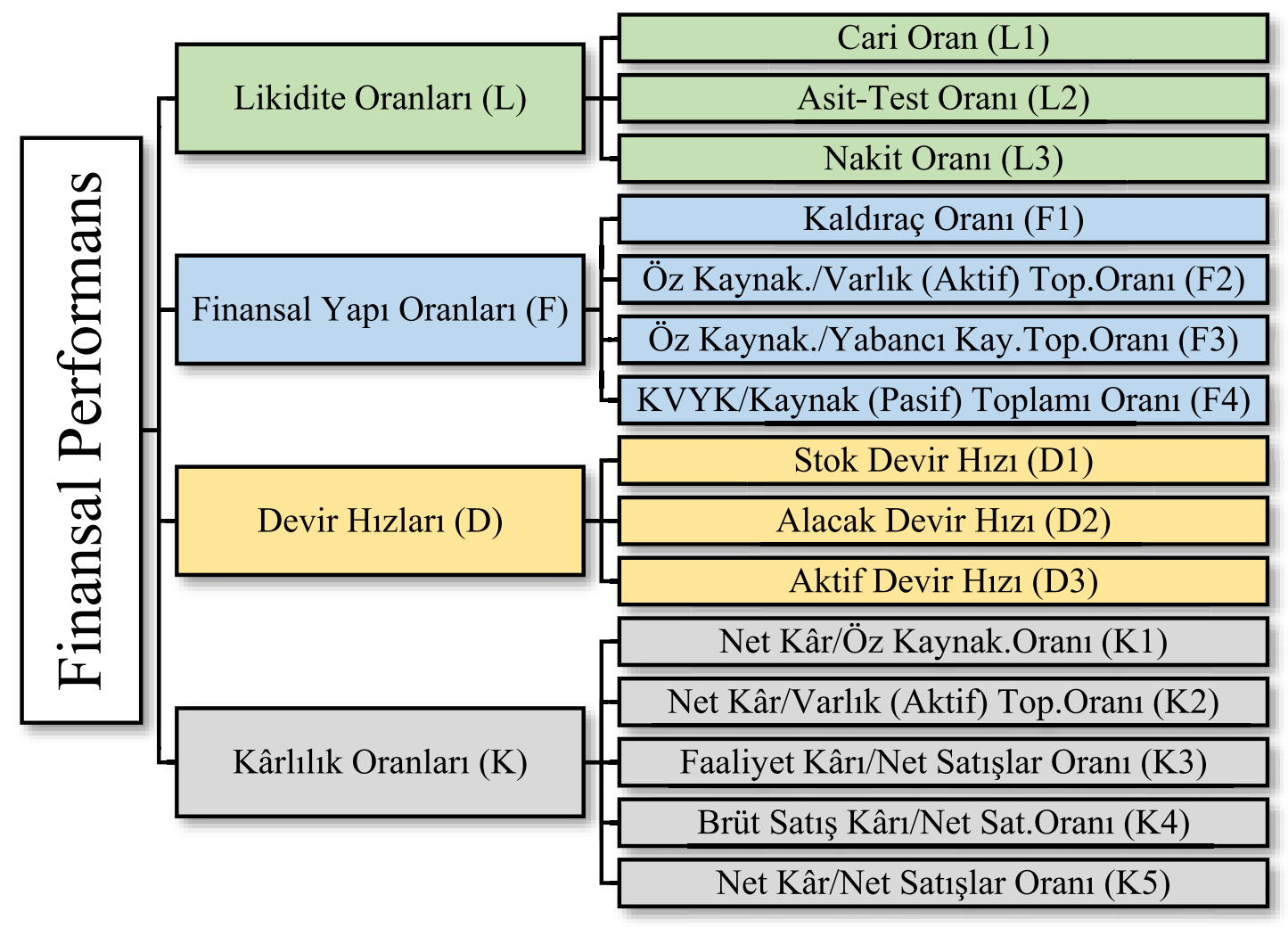

Şekil 1: Finansal Performansı Belirlemede Kullanılan Kriterler 


\subsection{AHP Yöntemi İle Kriter Ağırlıklarının Hesaplanması}

AHP yönteminin ilk basamağında, 7 uzman tarafından ikili karşılaştırmalar yapılmıştır. Uzmanların verdikleri yanıtların geometrik ortalamaları alınarak kriterlere ait ikili karşılaştırma matrisleri oluşturulmuştur. Bu işlemin ardından özdeğer yöntemiyle kriter ağırlıkları (w) elde edilmiştir. Alt kriterlerin sistemdeki ağırlıklarını bulmak içinse, yerel ağırlıkları, o kritere ait ana kriterin ağırlığı ile çarpılmıştır. Hesaplanan kriter ağırlıkları Tablo 4'te gösterilmektedir.

Kriter ağırlıklarının bulunmasının ardından, her bir matris için tutarlılık analizi yapılmaktadır. TutarIılık indekslerinin hesaplanması için öncelikle $\lambda_{\max }$ değerleri hesaplanmaktadır. Tutarlılık indekslerinin hesaplanmasının ardından, matris boyutuna göre Tablo 3'teki "Rassal İndeks $(R I)$ " değerleri kullanılarak tutarlılık oranları bulunmuştur.

Hesaplanan her bir matris için ayrı ayrı hesaplanan $\lambda_{\text {max }}$, "Tutarlılık İndeksi (TI)" ve "Tutarlılık Oranı (TO)" değerleri, Tablo 5'te verilmektedir. Yapılan hesaplamalar sonucunda, bütün ikili karşılaştırma matrisleri için tutarlılık oranları 0,10'dan düşük çıkmıştır ve finansal performansa etki eden hiyerarşik yapının her aşamasında modeller tutarlıdır.
Tablo 5: Hesaplanan $\lambda_{\max }$, Tutarlılık İndeksi ve Tutarlılık Oranı Değerleri

\begin{tabular}{lccc}
\hline & $\boldsymbol{\lambda}_{\max }$ & TI & TO \\
\hline Ana Kriterler Matrisi & 4,132 & 0,0441 & 0,05 \\
Likidite Oranları Matrisi & 3,006 & 0,0030 & 0,01 \\
Finansal Yapı Oranları Matrisi & 4,162 & 0,0539 & 0,06 \\
Devir Hızları Matrisi & 3,008 & 0,0040 & 0,01 \\
Kârlılık Oranları Matrisi & 5,196 & 0,0489 & 0,04 \\
\hline
\end{tabular}

\section{4. İşletmelerin Finansal Performanslarının Değerlendirilmesi}

Karar kriterlerinin ağırlıkları belirlendikten sonra, işletmelerin finansal performansları değerlendirilmiştir. Değerlendirmede kullanılan işletmelere ait finansal oranlar ile Karar Matrisi oluşturulmuş olup Tablo 6'da verilmektedir.

Karar Matrisinde, çalışmada değerlendirilen BIST Kimya, Petrol, Plastik Endeksi'nde (XKMYA) yer alan 24 işletme ve değerlendirmede kullanılan 15 kriter yer almaktadır. Oluşturulan matris, işletmelerin değerlendirilmesi amacıyla kullanılan VIKOR, TOPSIS, GRA ve MOORA yöntemlerinin hepsi için ortak Karar Matrisidir. Yöntemlerin hesaplamaları, Karar Matrisinin oluşturulmasından sonra farklılaşmaktadır.

Tablo 4: Kriter Ağırlıkları Tablosu

\begin{tabular}{|c|c|c|c|}
\hline Kodu & Oranlar & $\begin{array}{c}\text { Yerel } \\
\text { Ağırlık }\end{array}$ & $\begin{array}{l}\text { Sistemdeki } \\
\text { Ağırlık (w) }\end{array}$ \\
\hline $\mathrm{L}$ & Likidite & 0,26 & \\
\hline $\mathrm{F}$ & Finansal Yapı & 0,18 & \\
\hline $\mathrm{D}$ & Devir Hızları & 0,17 & \\
\hline $\mathrm{K}$ & Kârlılık & 0,39 & \\
\hline L1 & Cari & 0,27 & 0,069 \\
\hline L2 & Asit-Test & 0,22 & 0,058 \\
\hline L3 & Nakit & 0,51 & 0,132 \\
\hline $\mathrm{F} 1$ & Kaldıraç & 0,33 & 0,060 \\
\hline $\mathrm{F} 2$ & Öz Kaynak/Varlık Toplamı & 0,31 & 0,058 \\
\hline F3 & Öz Kaynak/Yab. Kay. Top. & 0,21 & 0,038 \\
\hline $\mathrm{F} 4$ & KVYK/Kaynak Toplamı & 0,15 & 0,028 \\
\hline D1 & Stok Devir Hızı & 0,30 & 0,051 \\
\hline D2 & Alacak Devir Hızı & 0,37 & 0,064 \\
\hline D3 & Aktif Devir Hızı & 0,33 & 0,056 \\
\hline $\mathrm{K} 1$ & Net Kâr/Öz Kaynak & 0,16 & 0,064 \\
\hline $\mathrm{K} 2$ & Net Kâr/Varlık Toplamı & 0,25 & 0,096 \\
\hline K3 & Faaliyet Kârı/Net Satışlar & 0,25 & 0,097 \\
\hline K4 & Brüt Satış Kârı/Net Sat. & 0,12 & 0,047 \\
\hline K5 & Net Kâr/Net Satışlar Oranı & 0,21 & 0,082 \\
\hline
\end{tabular}




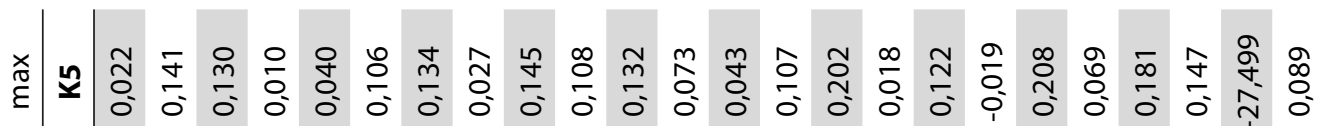

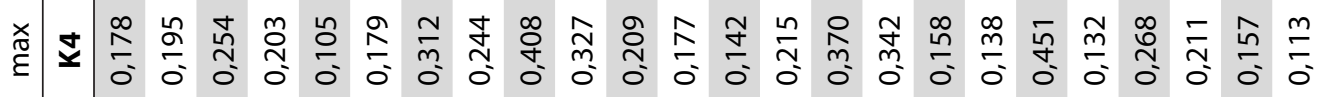

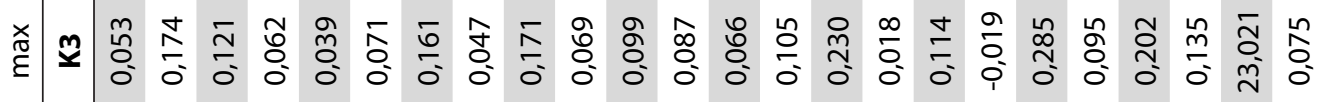

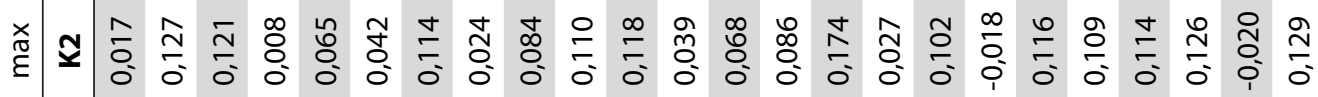

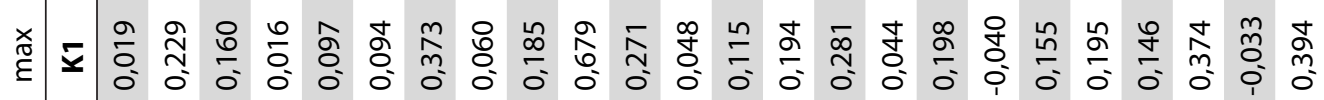

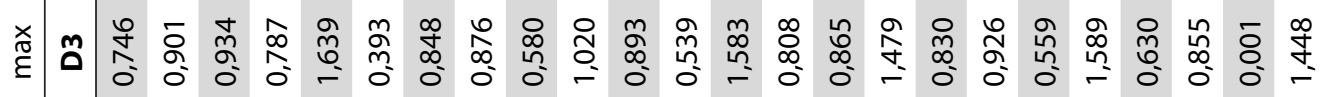

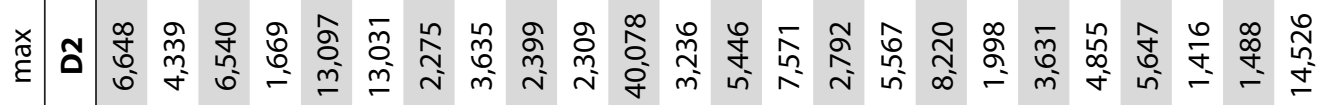

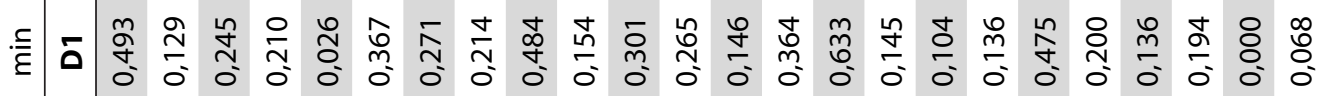

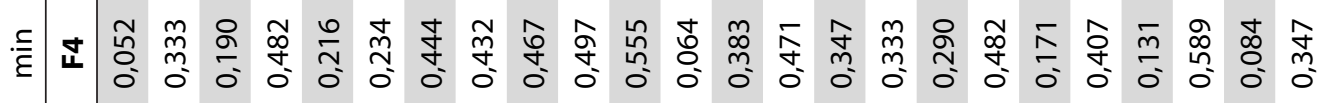

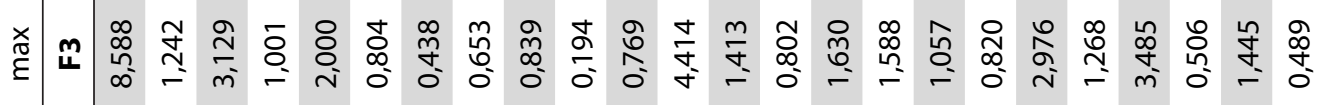

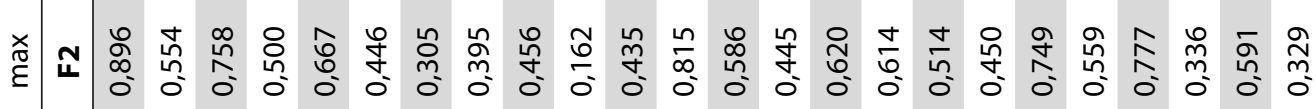

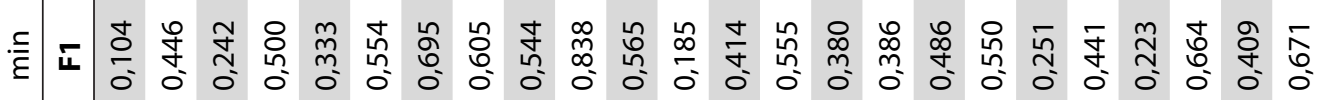

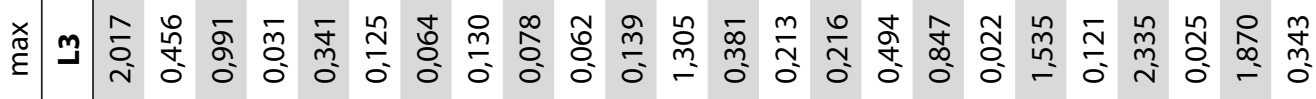

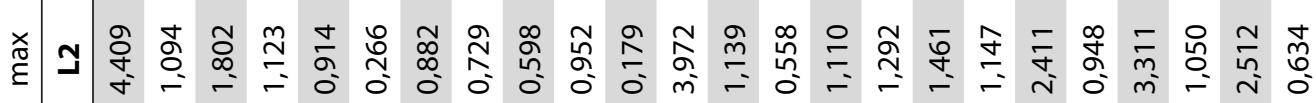




\subsubsection{VIKOR Yöntemi ile Finansal Performansların Değerlendirilmesi}

Karar Matrisinin oluşturulmasından sonra, VIKOR yöntemi ile işletmelerin finansal performanslarının değerlendirilmesi için işlem adımları uygulanarak $S_{i}$ ve $R_{i}$ değerleri hesaplanmıştır. $S_{i}$ ve $R_{i}$ değerlerinin hesaplanmasının ardından bu değerler aracılığı ile $Q_{i}$ değeri elde edilmiştir. Maksimum grup faydasını gösteren " $v$ " parametresi, literatürdeki kullanıma uygun olarak 0,50 alınmıştır. Elde edilen tüm bu değerler ve işletmelerin finansal performanslarının VIKOR yöntemine göre sıralaması Tablo 7'de verilmiştir.

\subsubsection{TOPSIS Yöntemi ile Finansal Performansların Değerlendirilmesi}

Gerek alternatiflerin değerlendirilmesi gerekse ÇKKV yöntemleri ile performans analizi çalışmalarında en sık kullanılan yöntemlerden birisi olan TOPSIS yöntemi de Karar Matrisi ile başlamaktadır. TOPSIS yöntemi işlem adımlarııın ardından değerlendirilen tüm işletmeler için hesaplanan $S_{i}^{*}$ ve $S_{i}^{-}$değerleri; bu değerlerden elde edilen ideal çözüme nispi yakınlığı gösteren $C_{i}^{*}$ değerleri ile bu değere göre işletmelerin sıralaması Tablo 7'de verilmektedir.

\subsubsection{GRA Yöntemi ile Finansal Performansların Değerlendirilmesi}

GRA yönteminde veri setinin hazırlanması ve Karar Matrisinin oluşturulmasının ardından, işlem adımları uygulanarak gri ilişkisel dereceler belirlenmiş olup, bu değerlerin küçükten büyüğe doğru sıralanmasıyla da işletmeler en yüksek performans gösterenden en düşük performans gösterene doğru sıralanmışlardır. İşlemler sırasında gri ilişkisel eşitliği uygulanırken ayırt edicilik indisi $\zeta=0,5$ alınmıştır. Hesaplanan gri ilişkisel dereceler ile bu derecelere göre sıralama sonuçları Tablo 7'de verilmektedir.

\subsubsection{MOORA Yöntemi ile Finansal Performansların Değerlendirilmesi}

MOORA yöntemi uygulama basamakları, alternatiflerin değerlendirildiği VIKOR, TOPSIS ve GRA yöntemlerindeki gibi “Karar Matrisi”ile başlamaktadır. MOORA işlem adımlarının uygulanmasının ardından performans göstergeleri olan $y_{i}^{*}$ değerleri elde edilmiştir. Bu değerler ile işletmelerin performans değerlerine göre sıraları Tablo 7'de verilmektedir.

Tablo 7: VIKOR, TOPSIS, GRA ve MOORA Elde Edilen Değerler ve Performans Sıralamaları

\begin{tabular}{|c|c|c|c|c|c|c|c|c|c|c|c|c|}
\hline & $S_{i}$ & $\begin{array}{l}\text { VIKOR } \\
S_{i} \text { SIra }\end{array}$ & $Q_{i}$ & $\begin{array}{l}\text { VIKOR } \\
Q_{i} \text { SIra }\end{array}$ & $S^{*}$ & $S^{-}$ & $C^{*}$ & $\begin{array}{l}\text { TOPSIS } \\
\text { Sira }\end{array}$ & $\Gamma_{0 i}$ & $\begin{array}{l}\text { GRA } \\
\text { Sira }\end{array}$ & $y_{i}^{*}$ & $\begin{array}{c}\text { MOORA } \\
\text { Sira }\end{array}$ \\
\hline ACSEL & 0,415 & 2 & 0,026 & 2 & 0,119 & 0,122 & 0,505 & 1 & 0,675 & 1 & 0,192 & 1 \\
\hline AKSA & 0,609 & 10 & 0,439 & 9 & 0,136 & 0,094 & 0,408 & 11 & 0,499 & 14 & 0,085 & 11 \\
\hline ALKIM & 0,516 & 5 & 0,163 & 5 & 0,126 & 0,098 & 0,438 & 6 & 0,541 & 6 & 0,126 & 5 \\
\hline ATPET & 0,742 & 23 & 0,957 & 23 & 0,150 & 0,085 & 0,362 & 23 & 0,442 & 22 & 0,023 & 23 \\
\hline AYGAZ & 0,599 & 8 & 0,515 & 10 & 0,137 & 0,093 & 0,402 & 13 & 0,528 & 8 & 0,088 & 10 \\
\hline BAGFS & 0,735 & 21 & 0,874 & 21 & 0,144 & 0,086 & 0,373 & 21 & 0,441 & 23 & 0,033 & 21 \\
\hline BRISA & 0,679 & 17 & 0,843 & 18 & 0,143 & 0,092 & 0,391 & 18 & 0,471 & 18 & 0,057 & 17 \\
\hline BRKSN & 0,737 & 22 & 0,873 & 20 & 0,147 & 0,085 & 0,366 & 22 & 0,442 & 21 & 0,027 & 22 \\
\hline DEVA & 0,704 & 20 & 0,866 & 19 & 0,146 & 0,088 & 0,376 & 20 & 0,462 & 19 & 0,039 & 20 \\
\hline DYOBY & 0,664 & 16 & 0,823 & 17 & 0,143 & 0,098 & 0,406 & 12 & 0,503 & 11 & 0,071 & 16 \\
\hline EGGUB & 0,633 & 14 & 0,719 & 14 & 0,136 & 0,103 & 0,430 & 7 & 0,506 & 10 & 0,095 & 8 \\
\hline GEDZA & 0,511 & 4 & 0,158 & 4 & 0,125 & 0,102 & 0,449 & 5 & 0,563 & 4 & 0,134 & 4 \\
\hline GOODY & 0,631 & 13 & 0,528 & 11 & 0,139 & 0,090 & 0,395 & 14 & 0,498 & 15 & 0,073 & 14 \\
\hline GUBRF & 0,697 & 19 & 0,751 & 16 & 0,141 & 0,088 & 0,384 & 19 & 0,454 & 20 & 0,049 & 19 \\
\hline HEKTS & 0,598 & 7 & 0,612 & 13 & 0,139 & 0,096 & 0,410 & 10 & 0,530 & 7 & 0,085 & 12 \\
\hline MRSHL & 0,616 & 11 & 0,419 & 8 & 0,139 & 0,090 & 0,392 & 17 & 0,502 & 12 & 0,075 & 13 \\
\hline PETKM & 0,600 & 9 & 0,281 & 7 & 0,131 & 0,094 & 0,420 & 8 & 0,497 & 16 & 0,095 & 7 \\
\hline PIMAS & 0,768 & 24 & 1,000 & 24 & 0,152 & 0,085 & 0,359 & 24 & 0,439 & 24 & 0,012 & 24 \\
\hline RTALB & 0,485 & 3 & 0,110 & 3 & 0,123 & 0,104 & 0,459 & 4 & 0,570 & 3 & 0,139 & 3 \\
\hline SASA & 0,634 & 15 & 0,736 & 15 & 0,141 & 0,092 & 0,395 & 15 & 0,501 & 13 & 0,072 & 15 \\
\hline SODA & 0,411 & 1 & 0,011 & 1 & 0,118 & 0,118 & 0,501 & 2 & 0,633 & 2 & 0,180 & 2 \\
\hline TMPOL & 0,684 & 18 & 0,880 & 22 & 0,143 & 0,093 & 0,393 & 16 & 0,473 & 17 & 0,057 & 18 \\
\hline TRCAS & 0,593 & 6 & 0,255 & 6 & 0,123 & 0,117 & 0,486 & 3 & 0,541 & 5 & 0,106 & 6 \\
\hline TUPRS & 0,621 & 12 & 0,543 & 12 & 0,135 & 0,097 & 0,417 & 9 & 0,511 & 9 & 0,091 & 9 \\
\hline
\end{tabular}




\subsection{Yöntemlerin Karşılaştırılması}

VIKOR (S ve Q olmak üzere), TOPSIS, GRA ve MOORA yöntemleri ile yapılan değerlendirme sonucunda, işletmelerin finansal performanslarına göre sıralamalarının grafiksel gösterimi Şekil 2'de yer almaktadır.

Şekil 2'de her işletmenin bu çalışmada kullanılan yöntemlere göre sıralama sonuçları görülmektedir. Grafik incelendiğinde her bir yönteme göre en iyi performansa sahip ACSEL, SODA, RTALB, GEDZA, TRCAS ve ALKIM kodlu ilk 6 işletmenin, değerlendirme yöntemi değişse bile ilk 6 'da yer aldığı görülmektedir. Yöntemlerden herhangi birine göre performans değerleri düşük olarak ölçülen işletmelerin diğer yöntemlerle değerlendirmelerine bakıldığında performanslarının düşük olduğu gözlemlenmiştir. Orta sıralarda ise büyük çapta olmayan yer değiştirmeler görülmektedir.

Performans değerlendirmesi yapılan yöntemlere göre sıralamaların ortalaması alındığı zaman oluşan yeni sıralama ve bu sıralamanın, çalışmada kullanılan yöntemlere göre farkları Tablo 8'de verilmektedir.

İşletmelerin finansal performanslarının değerlendirilmesinin ardından, yöntemler arasında farklılık olup olmadığına bakmak gerekmektedir. Şekil 2'de ve Tablo 8'de görülmekte olan sonuçlar, her bir yöntem için Spearman Sıra Korelasyon Katsayısı ile karşılaştırılmıştır ve sonuçlara Tablo 9'da yer verilmiştir.

Çalışmada işletmeleri değerlendirmek için birden fazla yöntem kullanılmış olması, bu yöntemlerin karşılaştırılmasına imkân tanıdığı için önem arz etmektedir. Elde edilen sonuçlara göre, bu çalışmada kullanılan yöntemlerin sonuçları birbirleri ile anlamlı şekilde pozitif ilişkilidirler. Bu sonuç çalışmada kullanılan yöntemlerin farklılık içermediğini ve bir yöntemin bir diğeri yerine kullanılabileceğini göstermektedir.

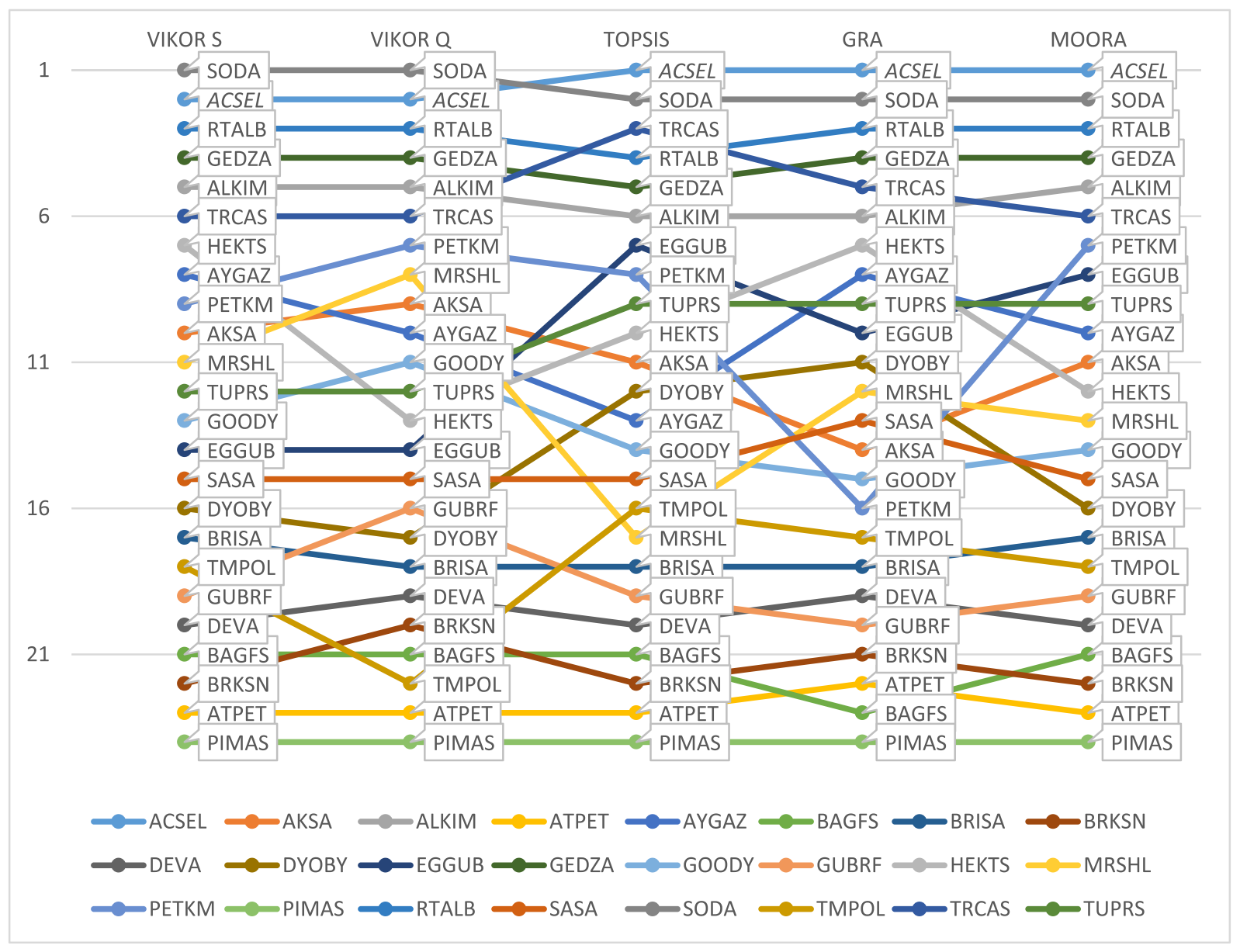

Şekil 2: Yöntemlerin Sonuçlarının Grafiksel Karşılaştırması 
Tablo 8: Yöntemlere Göre Sıralama ve Ortalama Sıralamaya Göre Farklar

\begin{tabular}{|c|c|c|c|c|c|c|c|c|c|c|c|}
\hline \multirow{2}{*}{$\frac{\text { Ort. }}{1}$} & \multirow{2}{*}{$\begin{array}{l}\text { Şirket } \\
\text { ACSEL }\end{array}$} & \multicolumn{2}{|c|}{ VIKOR S } & \multicolumn{2}{|c|}{ VIKOR Q } & \multicolumn{2}{|c|}{ TOPSIS } & \multicolumn{2}{|c|}{ GRA } & \multicolumn{2}{|c|}{ MOORA } \\
\hline & & 2 & $\downarrow$ & 2 & $\downarrow$ & 1 & $\leftrightarrow$ & 1 & $\leftrightarrow$ & 1 & $\leftrightarrow$ \\
\hline 2 & SODA & 1 & $\uparrow$ & 1 & $\uparrow$ & 2 & $\leftrightarrow$ & 2 & $\leftrightarrow$ & 2 & $\leftrightarrow$ \\
\hline 3 & RTALB & 3 & $\leftrightarrow$ & 3 & $\leftrightarrow$ & 4 & $\downarrow$ & 3 & $\leftrightarrow$ & 3 & $\leftrightarrow$ \\
\hline 4 & GEDZA & 4 & $\leftrightarrow$ & 4 & $\leftrightarrow$ & 5 & $\downarrow$ & 4 & $\leftrightarrow$ & 4 & $\leftrightarrow$ \\
\hline 5 & TRCAS & 6 & $\downarrow$ & 6 & $\downarrow$ & 3 & $\uparrow$ & 5 & $\leftrightarrow$ & 6 & $\downarrow$ \\
\hline 6 & ALKIM & 5 & $\uparrow$ & 5 & $\uparrow$ & 6 & $\leftrightarrow$ & 6 & $\leftrightarrow$ & 5 & $\uparrow$ \\
\hline 7 & PETKM & 9 & $\downarrow$ & 7 & $\leftrightarrow$ & 8 & $\downarrow$ & 16 & $\downarrow$ & 7 & $\leftrightarrow$ \\
\hline 8 & AYGAZ & 8 & $\leftrightarrow$ & 10 & $\downarrow$ & 13 & $\downarrow$ & 8 & $\leftrightarrow$ & 10 & $\downarrow$ \\
\hline 9 & HEKTS & 7 & $\uparrow$ & 13 & $\downarrow$ & 10 & $\downarrow$ & 7 & $\uparrow$ & 12 & $\downarrow$ \\
\hline 10 & TUPRS & 12 & $\downarrow$ & 12 & $\downarrow$ & 9 & $\uparrow$ & 9 & $\uparrow$ & 9 & $\uparrow$ \\
\hline 11 & EGGUB & 14 & $\downarrow$ & 14 & $\downarrow$ & 7 & $\uparrow$ & 10 & $\uparrow$ & 8 & $\uparrow$ \\
\hline 12 & AKSA & 10 & $\uparrow$ & 9 & $\uparrow$ & 11 & $\uparrow$ & 14 & $\downarrow$ & 11 & $\uparrow$ \\
\hline 13 & MRSHL & 11 & $\uparrow$ & 8 & $\uparrow$ & 17 & $\downarrow$ & 12 & $\uparrow$ & 13 & $\leftrightarrow$ \\
\hline 14 & GOODY & 13 & $\uparrow$ & 11 & $\uparrow$ & 14 & $\leftrightarrow$ & 15 & $\downarrow$ & 14 & $\leftrightarrow$ \\
\hline 15 & DYOBY & 16 & $\downarrow$ & 17 & $\downarrow$ & 12 & $\uparrow$ & 11 & $\uparrow$ & 16 & $\downarrow$ \\
\hline 16 & SASA & 15 & $\uparrow$ & 15 & $\uparrow$ & 15 & $\uparrow$ & 13 & $\uparrow$ & 15 & $\uparrow$ \\
\hline 17 & BRISA & 17 & $\leftrightarrow$ & 18 & $\downarrow$ & 18 & $\downarrow$ & 18 & $\downarrow$ & 17 & $\leftrightarrow$ \\
\hline 18 & TMPOL & 18 & $\leftrightarrow$ & 22 & $\downarrow$ & 16 & $\uparrow$ & 17 & $\uparrow$ & 18 & $\leftrightarrow$ \\
\hline 19 & GUBRF & 19 & $\leftrightarrow$ & 16 & $\uparrow$ & 19 & $\leftrightarrow$ & 20 & $\downarrow$ & 19 & $\leftrightarrow$ \\
\hline 20 & DEVA & 20 & $\leftrightarrow$ & 19 & $\uparrow$ & 20 & $\leftrightarrow$ & 19 & $\uparrow$ & 20 & $\leftrightarrow$ \\
\hline 21 & BAGFS & 21 & $\leftrightarrow$ & 21 & $\leftrightarrow$ & 21 & $\leftrightarrow$ & 23 & $\downarrow$ & 21 & $\leftrightarrow$ \\
\hline 22 & BRKSN & 22 & $\leftrightarrow$ & 20 & $\uparrow$ & 22 & $\leftrightarrow$ & 21 & $\uparrow$ & 22 & $\leftrightarrow$ \\
\hline 23 & ATPET & 23 & $\leftrightarrow$ & 23 & $\leftrightarrow$ & 23 & $\leftrightarrow$ & 22 & $\uparrow$ & 23 & $\leftrightarrow$ \\
\hline 24 & PIMAS & 24 & $\leftrightarrow$ & 24 & $\leftrightarrow$ & 24 & $\leftrightarrow$ & 24 & $\leftrightarrow$ & 24 & $\leftrightarrow$ \\
\hline
\end{tabular}

5 değerlendirme yönteminin sıralama ortalamasına göre:

$\uparrow$ daha yüksek $\downarrow$ daha düşük $\leftrightarrow$ aynı

Tablo 9: Spearman Korelasyon Katsayısı ile Yöntemlerin Karşılaştırılması

\begin{tabular}{crrrrr}
\hline Spearman $\boldsymbol{P}$ & VIKOR S & VIKOR Q & TOPSIS & \multicolumn{1}{c}{ GRA } & MOORA \\
\hline VIKOR S & 1,000 &, 961 &, 928 &, 940 &, 963 \\
VIKOR Q &, 961 & 1,000 &, 887 &, 872 &, 949 \\
TOPSIS &, 928 &, 887 & 1,000 &, 930 &, 972 \\
GRA &, 940 &, 872 &, 930 & 1,000 &, 928 \\
MOORA &, 963 &, 949 &, 972 &, 928 & 1,000 \\
\hline
\end{tabular}

\section{SONUÇ}

Çalışanın amacı ÇKKV yöntemlerinin finansal performans analizinde kullanılabilirliğini göstermeye çalışılmak ve kullanılan yöntemlere ait sonuçların birbirleri arasındaki farkı gözlemlemektir. İnsan hayatındaki faktörlerin önem derecelerinin farklı olması gibi, işletmeler için de değişik faktörler, farklı önem derecelerine sahiptir. Bu yüzden, kriterlerin önem derecelerinin belirlenerek performans analizi yapılması önemlidir. Kriterlerin seçimi ve ağılıklandırılması basamağında öznel görüşlerin kısmi olarak yer aldığı, alternatiflerin değerlendirilmesi aşamasında ise objektif bilanço verilerinin kullanıldığı bu çalışma ile BiST Kimya, Petrol, Plastik Endeksi'nde yer alan işletmelerin finansal performansları analiz edilmiştir.

Uygulamada kullanılan 4 ana kriteri ve 15 alt kriteri ağırlıklandırmak için, uzman görüşlerine dayalı olarak AHP yöntemi kullanılmıştır. Kriterlerin ağırlık- 
landırılmasının ardından VIKOR, TOPSIS, GRA ve MOORA yöntemleriyle işletmeler değerlendirilmiştir. Bu değerlendirmenin ardından ise yöntemler arasında farklılık olup olmadığı test edilmiştir.

Elde edilen bulgular literatür ile karşılaştırılarak sonuçların tutarlıı̆ı üzerine yorum yapılabilecektir. Öncelikle ana kriterler ele alınacak olursa, kârlılık oranları uzman görüşlerine göre 0,39 ile finansal performansı etkileyen en önemli ana kriter durumundadır. Bu sonuç literatürdeki bu konuda yapılmış çalışmalarla benzerlik göstermektedir. Alt kriterlere ait ağırlıklar değerlendirilecek olursa; likidite oranları ana kriterinde nakit oranı (L3), finansal yapı oranlarında en önemli iki alt kriter sırasıyla kaldıraç oranı (F1) ve öz kaynaklar/varlık (aktif) toplamı oranı (F2), kârlılık oranları ana kriterinde ise net kâr/varlık (aktif) toplamı oranı (K2), faaliyet kârı/net satışlar oranı (K3) ve net kâr/net satışlar oranı (K5) en önemli kriterler olarak bulunmuştur. Böylelikle çalışmadaki finans uzmanlarına ait görüşlerin literatür ile paralellik gösterdiğini söylemek mümkündür.

BIST XKMYA sektörü daha önceden finansal performans analizine tabi tutulmadığı için, sektörel bir sonuç karşılaştırması yapmak mümkün olmamıştır. Ayrıca BIST'te yer alan bütün endeksleri analiz etmek; verilerin çokluğu, uygulama zorluğu ve zaman kısıtı sebebiyle çalışmanın sınırııı̆ını oluşturmaktadır.

Çalışmanın önemli adımlarından birisi olan ÇKKV yöntemlerinin karşılaştırılması ise daha önceden yapılmış uygulamalarla benzerlik göstermektedir.
Antucheviciene vd. (2011), Athawale ve Chakraborty (2011), Çalışkan vd. (2012), Poklepović ve Babić (2014) ve Ağaç vd. (2015) yaptıkları çalışmalarda ÇKKV yöntemlerinin benzer sonuçlar verdiklerini gözlemlemişlerdir.

Bundan sonra yapılan çalışmalarda daha fazla sayıda ÇKKV yöntemini ve bu çalışmada yer almayan ÇKKV yöntemlerini karşılaştırmanın literatüre olumlu yönde katkıda bulunacağı düşünülmektedir. Finansal performans analizi dışındaki uygulama alanlarında da yapılacak çok yöntemli alternatif değerlendirmesi ve buna bağlı olarak yöntemlerin karşılaştırmasını yapmak da çalışmalara konu edilebilir.

Kimya, Petrol, Plastik sektörü dışında kalan sektörler için yapılacak uygulamalarda, bu çalışmada kullanılan yöntemler kullanılabilir. Böylelikle BiST'te yer alan diğer sektörlerdeki işletmelerin de finansal performansları analiz edilebilecektir. Bu yöntemler sadece işletmeler için değil, sektörlerin finansal performanslarını analiz etmek için de sonraki çalışmalarda kullanılabilir.

Karar verici veya yatırımcının beklentilerine göre seçilecek ve bu çalışmadakinden farklı kriterler ile yapılacak uygulamalarda, sektör aynı kalsa bile sonuçların değişmesi mümkün olabilecektir. Bu sebeple, farklı önceliklere sahip olan karar vericiler ile de Kimya, Petrol, Plastik sektöründe yer alan işletmelerin analiz edilmesi ve sonuçların karşılaştırılması daha sonraki çalışmaların konusu olabilir.

\section{KAYNAKLAR}

Ağaç, G., Baki, B., Peker, I. Ve Ar, İ. M. (2015) “Çok Kriterli Karar Verme Tekniklerini Kullanarak Serbest Bölge Yer Seçimi: Doğu Anadolu Bölgesi Örneği" Dokuz Eylül Üniversitesi IïBF Dergisi, 30(1): 79-113.

Aksoy, D. (2011) Türkiye'deki Mevduat Bankalarının Finansal Performanslarının Ölçümü Üzerine Bir Uygulama, Yüksek Lisans Tezi, Marmara Üniversitesi, Sosyal Bilimler Enstitüsü, İstanbul, 2011.

Akyüz, Y., Bozdoğan, T. ve Hantekin, E. (2011) "TOPSIS Yöntemiyle Finansal Performansın Değerlendirilmesi ve Bir Uygulama" Afyon Kocatepe Üniversitesi, Ï̈BF Dergisi, 13(1): 73-92.

Alonso, J. A. ve Lamata, M. T. (2006) "Consistency in the Analytic Hierarchy Process: A New Approach" International Journal of Uncertainty, Fuzziness and Knowledge-Based Systems, 14(4): 445-459.
Antucheviciene, J., Zakarevicius, A. ve Zavadskas, E. K. (2011) "Measuring Congruence of Ranking Results Applying Particular MCDM Methods" Informatıca, 22(3): 319-338.

Athawale, V. M. ve Chakraborty, S. (2011) "A Comparative Study on The Ranking Performance of Some MultiCriteria Decision-Making Methods for Industrial Robot Selection" International Journal of Industrial Engineering Computations, 2: 831-850.

Aytekin, S. ve Sakarya, Ş. (2013) "BiST'de İşlem Gören Gıda İşletmelerinin TOPSIS Yöntemi ile Finansal Performanslarının Değerlendirilmesi" Yönetim ve Ekonomi Araştırmaları Dergisi, Sayı 21: 30-47.

Bakırcl, F., Shiraz, S. E. ve Sattary, A. (2014) "BIST'da Demir, Çelik Metal Ana Sanayii Sektöründe Faaliyet Gösteren İşletmelerin Finansal Performans Analizi: VZA 
Süper Etkinlik ve TOPSIS Uygulaması", Ege Akademik Bakış, 14(1): 9-19.

Baležentis, A., Baležentis, T. ve Misiūnas, A. (2012) “An Integrated Assessment of Lithuanian Economic Sectors Based on Financial Ratios and Fuzzy MCDM Methods" Technological and Economic Development of Economy, 18(1): 34-53.

Bayrakdaroglu, A. ve Yalçın, N. (2012) “Strategic Financial Performance Evaluation of the Turkish Companies Traded on ISE" Ege Akademik Bakış, 12(4): 529-539.

Behzadian, M., Otaghsara, S. K., Yazdani, M. ve Ignatius, J. (2012) "A State-of the-Art Survey of TOPSIS Applications" Expert Systems with Applications, 39: 13051-13069.

Bektaş, H. ve Tuna, K. (2013) "Borsa İstanbul Gelişen İşletmeler Piyasası'nda İşlem Gören Firmaların Gri İlişkisel Analiz ile Performans Ölçümü" Çankırı Karatekin Üniversitesi İktisadi ve İdari Bilimler Fakültesi Dergisi, 3(2): 185-198.

Brauers, W. K. M. ve Zavadskas, E. K. (2006) "The MOORA Method and Its Application to Privatization in a Transition Economy" Control and Cybernetics, 35(2): 445-469.

Bülbül, S. ve KÖSE, A. (2011) "Türk Gıda Şirketlerinin Finansal Performansının Çok Amaçlı Karar Verme Yöntemleriyle Değerlendirilmesi" Atatürk Ü. IïFF Dergisi, 10. Ekonometri ve İstatistik Sempozyumu Özel Sayısı: 71-97.

Chan, J. W. K. ve Tong, T. K. L. (2007) "Multi-Criteria Material Selections and End-of-Life Product Strategy: Grey Relational Analysis Approach", Materials and Design, 28: 1539-1546.

Chang, C-L., Tsai, C-H. ve Chen, L. (2003) “Applying Grey Relational Analysis to the Decathlon Evaluation Model" International Journal of The Computer, The Internet and Management, 11(3): 54-62.

Chen, C-T. (2000) "Extensions of the TOPSIS for Group Decision-Making Under Fuzzy Environment" Fuzzy Sets and Systems, 114: 1-9.

Çalışkan H., Kurşuncu B., Kurbanoğlu C. ve Güven Ş.Y. (2012) "TOPSIS Metodu Kullanılarak Kesici Takım Malzemesi Seçimi" Makine Teknolojileri Elektronik Dergisi, 9: 35-42.

Çelen, A. (2014) "Comparative Analysis of Normalization Procedures in TOPSIS Method: With an Application to Turkish Deposit Banking Market" INFORMATICA, 25(2): 185-208.

Çonkar, K., Elitaş, C. ve Atar, G. (2011) “iMKB Kurumsal Yönetim Endeksi'ndeki (XKURY) Firmaların Finansal Performanslarının TOPSIS Yöntemi İle Ölçümü Ve
Kurumsal Yönetim Notu İle Analizi" İktisat Fakültesi Mecmuası, 61(1): 81-115.

Demireli, E. (2010) "TOPSIS Çok Kriterli Karar Verme Sistemi: Türkiye'deki Kamu Bankaları Üzerine Bir Uygulama" Girişimcilik ve Kalkınma Dergisi, 5(1): 101112.

Deng, J. (1989) "Introduction to Grey System Theory" The Journal of Grey System, 1: 1-24.

Dolan, J. G. (2008) "Shared Decision-Making Transferring Research into Practice: The Analytic Hierarchy Process (AHP)" Patient Education and Counseling, 73: 418-425.

Dumanoğlu, S. (2010) “iMKB'de İşlem Gören Çimento Şirketlerinin Mali Performansının TOPSIS Yöntemi ile Değerlendirilmesi" Marmara Üniversitesi IiBF Dergisi, 29(2): 323-339.

Dumanoğlu, S. ve Ergül, N. (2010) “iMKB'de İşlem Gören Teknoloji Şirketlerinin Mali Performans Ölçümü" MUFAD Journal, 48: 101-111.

Ergül, N. (2014) "BiST- Turizm Sektöründeki Şirketlerin Finansal Performans Analizi" Çankırı Karatekin Üniversitesi İktisadi ve İdari Bilimler Fakültesi Dergisi, 4(1): 325-340.

Ertuğrul, İ. ve Karakaşoğlu, N. (2009) "Performance Evaluation of Turkish Cement Firms with Fuzzy Analytic Hierarchy Process and TOPSIS Methods" Expert Systems with Applications, 36: (702-715).

Ertuğrul, M. (2009) "Finansal Performans Ölçümünde Dönüşümlerin Türkiye Açısından Değerlendirilmesi" Anadolu Üniversitesi Sosyal Bilimler Dergisi, 9(1): 19-46.

Esbouei, S. K., Ghadikolaei, A. S. ve Antucheviciene, J. (2014) "Using FANP and Fuzzy VIKOR for Ranking Manufacturing Companies Based On Their Financial Performance" Economic Computation \& Economic Cybernetics Studies \& Research, 48(3): 141-162.

Feng, C-M. Ve Wang, R-T. (2001) "Considering the financial ratios on the performance evaluation of highway bus industry" Transport Reviews, 21(4): 449467.

Feng, C-M. ve Wang, R-T. (2000) “Performance Evaluation for Airlines Including the Consideration of Financial Ratios" Journal of Air Transport Management, 6: 133-142.

Fung, C-P. (2003) "Manufacturing Process Optimization for Wear Property of Fiber-Reinforced Polybutylene Terephthalate Composites with Grey Relational Analysis" Wear, 254: 298-306.

Ghadikolaei, A. S., Esbouei, S. K. ve Antucheviciene, J. (2014) "Applying Fuzzy MCDM for Financial Performance Evaluation of Iranian Companies" Technological and Economic Development of Economy, 20(2): 274-291. 
Görener, A. (2011) "Bütünleşik ANP-VIKOR Yaklaşımı İle ERP Yazılımı Seçimi" Havacılık ve Uzay Teknolojileri Dergisi, 5(1): 97-110.

Ho, W. (2008) "Integrated Analytic Hierarchy Process and Its Applications - A Literature Review" European Journal of Operational Research, 186: 211-228.

Hsu, L-C. (2015) “Using a Decision-Making Process to Evaluate Efficiency and Operating Performance for Listed Semiconductor Companies" Technological And Economic Development of Economy, 21(2): 301-331.

Ishizaka, A. ve Nemery, P. (2013) Multi-Criteria Decision Analysis Methods and Software, Wiley.

iç, Y. T., Tekin, M., Pamukoğlu, F. Z. ve Yıldırım, S. E. (2015) "Kurumsal Firmalar İçin Bir Finansal Performans Karşılaştırma Modelinin Geliştirilmesi" Gazi Üniv. Müh. Mim. Fak. Der., 30(1): 71-85.

Jahanshahloo, G.R., Lotfi, F. H. ve Izadikhah, M. (2006) "An Algorithmic Method to Extend TOPSIS for Decision-Making Problems with Interval Data" Applied Mathematics and Computation, 175: 1375-1384.

Kuo, Y., Yang, T. ve Huang, G-W. (2008) "The Use of Grey Relational Analysis in Solving Multiple Attribute Decision-Making Problems" Computers \& Industrial Engineering, 55: 80-93.

Liu, S., Forrest, J. ve Yang, Y. (2012) “A Brief Introduction to Grey Systems Theory" Grey Systems: Theory and Application, 2(2): 89-104.

Omoniwa, B. (2014) "A Solution to Multi Criteria Robot Selection Problems Using Grey Relational Analysis" International Journal of Computer and Information Technology, 03(2): 328-332.

Opricovic, S. ve Tzeng, G-H. (2004) "Compromise Solution by MCDM Methods: A Comparative Analysis of VIKOR and TOPSIS" European Journal of Operational Research, 156: 445-455.

Opricovic, S. ve Tzeng, G-H. (2007) "Extended VIKOR Method in Comparison with Other Outranking Methods" European Journal of Operational Research, 178: 514-529.

Ömürbek, N. ve Özcan, A. (2016) "BIST'de İşlem Gören Sigorta Şirketlerinin MULTIMOORA Yöntemiyle Performans Ölçümü" Uluslararası Işletme, Ekonomi ve Yönetim Perspektifleri Dergisi, 1(2): 64-75.

Özdağoğlu, A. (2014) "Normalizasyon Yöntemlerinin Çok Ölçütlü Karar Verme Sürecine Etkisi-Moora Yöntemi İncelemesi" Ege Akademik Bakış, 14(2): 283-294.

Özdemir, A. İ. ve Deste, M. (2009) "Gri İlişkisel Analiz Ile Çok Kriterli Tedarikçi Seçimi: Otomotiv Sektöründe Bir Uygulama" İstanbul Üni. İşletme Fakültesi Dergisi, 38(2): 147-156.
Özer,M.A.(2009)“PerformansYönetimiUygulamalarında Performansın Ölçümü ve Değerlendirilmesi" Sayıştay Dergisi, 73: 3-29.

Özden, Ü. H., Başar, Ö. D. ve Kalkan, S. B. (2012) “iMKB'de İşlem Gören Çimento Sektöründeki Şirketlerin Finansal Performanslarının VIKOR Yöntemi ile Sıralanması" Ekonometri ve Istatistik, 17: 23-44.

Peker, İ. ve Baki, B. (2011) “Gri llişkisel Analiz Yöntemiyle Türk Sigortacilık Sektöründe Performans Ölçümü" Uluslararası İktisadi ve Idari Incelemeler Dergisi, 7: 1-18.

Perçin, S. ve Karakaya, A. (2012) “Bulanık Karar Verme Yöntemleriyle Türkiye'de Bilişim Teknolojisi Firmalarının Finansal Performanslarının Değerlendirilmesi" Marmara Üniversitesi i.I..B. Dergisi, 33(2): 241-266.

Poklepović, T. ve Babić, Z. (2014) “Stock selection using a hybrid MCDM approach" Croatian Operational Research Review, 5: 273-290.

Saaty, T. L. (1977) "A Scaling Method for Priorities in Hierarchical Structures" Journal of Mathematical Psychology, 15: 234--281.

Saaty, T. L. (1986) "Axiomatic Foundation of the Analytic Hierarchy Process" Management Science, 32(7): 841-855.

Saaty, T. L. (1980) The Analytical Hierarchical Process, Wiley, New York.

Saldanlı, A. ve Sırma, İ. (2014) "TOPSIS Yönteminin Finansal Performans Göstergesi Olarak Kullanılabilirliği" Marmara Üniversitesi Öneri Dergisi, 41: 185-202.

Seçme, N. Y., Bayrakdaroğlu, A. ve Kahraman, C. (2009) "Fuzzy Performance Evaluation in Turkish Banking Sector Using Analytic Hierarchy Process and TOPSIS" Expert Systems with Applications, 36: 11699-11709.

Sekreter, M. S., Akyüz, G. ve Çetin, E. I. (2004) “Şirketlerin Derecelendirilmesine İlişkin Bir Model Önerisi: Gıda Sektörüne Yönelik Bir Uygulama" Akdeniz i.I.B.F. Dergisi, 8: 139-155.

Shaverdi, M., Heshmati, M. R. ve Ramezani, I. (2014) "Application of Fuzzy AHP Approach for Financial Performance Evaluation of Iranian Petrochemical Sector" Procedia Computer Science, 31: 995-1004.

Shen, K-Y. ve Tzeng, G-H. (2015) "A Decision RuleBased Soft Computing Model for Supporting Financial Performance Improvement of The Banking Industry" Soft Comput, 19: 859-874.

Shih, H-S., Shyur, H-J. ve Lee, E. S. (2007) "An Extension of TOPSIS for Group Decision Making" Mathematical and Computer Modelling, 45: 801-813.

Soba, M., Akcanlı, F. ve Erem, I. (2012) “iMKB'ye Kayıtlı Seçilmiş İşletmelere Yönelik Etkinlik Ölçümü ve Performans Değerlendirmesi: Veri Zarflama Analizi ve 
TOPSIS Uygulaması", Selçuk Üniversitesi Sosyal Bilimler Enstitüsü Dergisi, 27: 229-243.

Stanujkic, D., Magdalinovic, N., Stojanovic, S. ve Jovanovic, R. (2012) “Extension of Ratio System Part of MOORA Method for Solving Decision-Making Problems with Interval Data", Informatica, 23(1): 141-154.

Tayyar, N., Akcanlı, F., Genç, E. ve Erem, I. (2014) “BiST'e Kayıtlı Bilişim ve Teknoloji Alanında Faaliyet Gösteren İşletmelerin Finansal Performanslarının Analitik Hiyerarşi Prosesi (AHP) ve Gri İlişkisel Analiz (GiA) Yöntemiyle Değerlendirilmesi" MUFAD Journal, 61: 19-40.

Tsai, C-H., Chang, C-L. ve Chen, L. "Applying Grey Relational Analysis to the Vendor Evaluation Model" International Journal of The Computer, The Internet and Management, 11(3): 45-53.

Türkmen, S. Y. ve Çağıl, G. (2012) “IMKB'ye Kote Bilişim Sektörü Şirketlerinin Finansal Performanslarının TOPSIS Yöntemi ile Değerlendirilmesi" Maliye Finans Yazıları, 95: 59-78.

Uygurturk, H. ve Korkmaz, T. (2012) "Finansal Performansın TOPSIS Çok Kriterli Karar Verme Yöntemi Ille Belirlenmesi: Ana Metal Sanayi İsletmeleri Üzerine Bir Uygulama" Eskişehir Osmangazi Üniversitesi IIBF Dergisi, 7(2): 95-115.

Uygurtürk, H. (2015) "Bankaların İnternet Şubelerinin Bulanık MOORA Yöntemi ile Değerlendirilmesi" Uluslararası Yönetim iktisat ve Işletme Dergisi, 25: 115128.

Vaidya, O. S. Ve Kumar, S. (2006) "Analytic Hierarchy Process: An Overview of Applications" European Journal of Operational Research, 169: 1-29.

Wang, Y-J. (2008) "Applying FMCDM to Evaluate Financial Performance of Domestic Airlines in Taiwan" Expert Systems with Applications, 34: 1837-1845.

Wang, Y-J. (2009) "Combining Grey Relation Analysis with FMCGDM to Evaluate Financial Performance of Taiwan Container Lines" Expert Systems with Applications, 36: 2424-2432.
Wang, Y-J. ve Lee, H-S. (2010) "Evaluating Financial Performance of Taiwan Container Shipping Companies by Strength and Weakness Indices"International Journal of Computer Mathematics, 87(1): 38-52.

Wu, H-H. (2002) "A Comparative Study of Using Grey Relational Analysis in Multiple Attribute Decision Making Problems" Quality Engineering, 15(2): 209-217.

Yalçın, N., Bayrakdaroğlu, A. ve Kahraman, C. (2012) "Application of Fuzzy Multi-Criteria Decision Making Methods for Financial Performance Evaluation of Turkish Manufacturing Industries" Expert Systems with Applications, 39: 350-364.

Yayar, R. ve Baykara, H. V. (2012) "TOPSIS Yöntemi ile Katııım Bankalarının Etkinliği ve Verimliliği Üzerine Bir Uygulama" Business and Economics Research Journal, 3(4): 21-42.

Yıldııı, B. F. (2014) "Gri İlişkisel Analiz" Yıldırım, B. F. ve ÖNDER, E. (eds.), Operasyonel, Yönetsel ve Stratejik Problemlerin Çözümünde Çok Kriterli Karar Verme Yöntemleri, Bursa, Dora Yayıncılık, 229-244.

Yıldız, A. ve Deveci, M. (2013)“Bulanık VIKOR Yöntemine Dayalı Personel Seçim Süreci" Ege Akademik Bakış, 13(4): 427-436.

Yurdakul, M. ve İç, Y. T. (2003) "Türk Otomotiv Firmalarının Performans Ölçümü ve Analizine Yönelik TOPSIS Yöntemini Kullanan Bir Örnek Çalışma" Gazi Üniv. Müh. Mim. Fak. Der., 18(1): 1-18.

Zahedi, F. (1986) "The Analytic Hierarchy Process - A Survey of the Method and its Applications" Interfaces, 16(4): 96-108.

Zhai, L-Y., Khoo, L-P. ve Zhong, Z-W. (2009) "Design Concept Evaluation in Product Development Using Rough Sets and Grey Relation Analysis" Expert Systems with Applications, 36: 7072-7079.

Zanakis, S. H., Solomon, A., Wishart, N. ve Dublish, S. (1998) "Multi-Attribute Decision Making: A Simulation Comparison of Select Methods" European Journal of Operational Research, 107: 507-529.

Zionts, S. (1979) "MCDM:"If Not a Roman Numeral, then What?" Interfaces, 9(4): 94-101. 